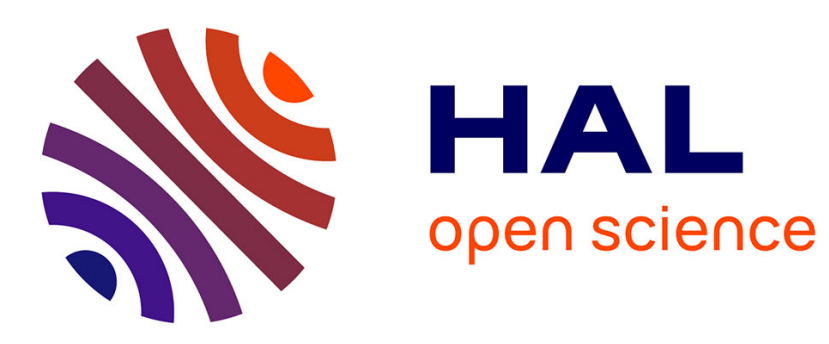

\title{
Measured and modeled dry deposition velocities over the ESCOMPTE area
}

\author{
Martine Michou, Patricia Laville, Dominique Serça, Angeliki Fotiadi, \\ Vincent-Henri Peuch
}

\section{To cite this version:}

Martine Michou, Patricia Laville, Dominique Serça, Angeliki Fotiadi, Vincent-Henri Peuch. Measured and modeled dry deposition velocities over the ESCOMPTE area. Atmospheric Research, 2005, 74 (1-4), pp.89-116. 10.1016/j.atmosres.2004.04.011 . hal-00135884

\section{HAL Id: hal-00135884 \\ https://hal.science/hal-00135884}

Submitted on 1 Feb 2022

HAL is a multi-disciplinary open access archive for the deposit and dissemination of scientific research documents, whether they are published or not. The documents may come from teaching and research institutions in France or abroad, or from public or private research centers.
L'archive ouverte pluridisciplinaire HAL, est destinée au dépôt et à la diffusion de documents scientifiques de niveau recherche, publiés ou non, émanant des établissements d'enseignement et de recherche français ou étrangers, des laboratoires publics ou privés.

\section{다)(1) $(5$}

Distributed under a Creative Commons Attribution - NonCommerciall 4.0 International 


\title{
Measured and modeled dry deposition velocities over the ESCOMPTE area
}

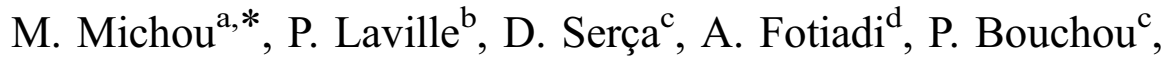 \\ V.-H. Peuch ${ }^{\mathrm{a}}$ \\ ${ }^{a}$ Météo-France, Centre National de Recherches Météorologiques, Toulouse, France \\ ${ }^{\mathrm{b}}$ INRA, Environnement et Grandes Cultures, Thiverval-Grignon, France \\ ${ }^{\mathrm{c}}$ Laboratoire d'Aérologie, Toulouse, France \\ ${ }^{\mathrm{d}}$ University of Ioannina, Laboratory of Meteorology, Ioannina, Greece
}

Measurements of the dry deposition velocity of ozone have been made by the eddy correlation method during ESCOMPTE (Etude sur Site pour COntraindre les Mode'les de Pollution atmosphe'rique et de Transport d'Emissions). The strong local variability of natural ecosystems was sampled over several weeks in May, June and July 2001 for four sites with varying surface characteristics. The sites included a maize field, a Mediterranean forest, a Mediterranean shrub-land, and an almost bare soil. Measurements of nitrogen oxide deposition fluxes by the relaxed eddy correlation method have also been carried out at the same bare soil site. An evaluation of the deposition velocities computed by the surface module of the multiscale Chemistry and Transport Model MOCAGE is presented. This module relies on a resistance approach, with a detailed treatment of the stomatal contribution to the surface resistance. Simulations at the finest model horizontal resolution (around $10 \mathrm{~km}$ ) are compared to observations. If the seasonal variations are in agreement with the literature, comparisons between raw model outputs and observations, at the different measurement sites and for the specific observing periods, are contrasted. As the simulated meteorology at the scale of $10 \mathrm{~km}$ nicely captures the observed situations, the default set of surface characteristics (averaged at the resolution of a grid cell) appears to be one of the main reasons for the

* Corresponding author. Fax: +33 561079610.

E-mail addresses: martine.michou@meteo.fr (M. Michou), laville@grigon.inra.fr (P. Laville), serd@aero.obs-mip.fr (D. Serça), afotiadi@cc.uoi.gr (A. Fotiadi), boup@aero.obs-mip.fr (P. Bouchou), vincent-henri.peuch@meteo.fr (V.-H. Peuch). 
discrepancies found with observations. For each case, sensitivity studies have been performed in order to see the impact of adjusting the surface characteristics to the observed ones, when available. Generally, a correct agreement with the observations of deposition velocities is obtained. This advocates for a sub-grid scale representation of surface characteristics for the simulation of dry deposition velocities over such a complex area. Two other aspects appear in the discussion. Firstly, the strong influence of the soil water content to the plant response, specifically in conditions of stress, is confirmed. Second, we point out the difficulty in interpreting measurements of nitrogen oxide deposition velocities: a synergetic approach combining measurements and modeling is practical.

Keywords: Dry deposition; Surface resistance; Stomatal resistance; Chemistry and Transport Model

\section{Introduction}

Dry deposition onto soils and plants is a major sink for a number of primary pollutants and of their photochemical products, such as ozone $\left(\mathrm{O}_{3}\right)$ or nitric acid $\left(\mathrm{HNO}_{3}\right)$. Several studies have outlined its strong temporal and spatial variability, and thus the need to parameterize it depends dynamically on surface cover and meteorological parameters, both for the time and space scales of chemistry-climate interaction (Ganzeveld and Lelieveld, 1995; Ganzeveld et al., 1998), and for the simulation of continental to regional air pollution episodes (Wesely and Hicks, 2000). Currently, the relative uncertainty on the numerical simulation of deposition velocities depending on location and time, for a range of compounds involved in the chemistry of tropospheric $\mathrm{O}_{3}$ and of its precursors, is probably bigger than the one concerning the surface concentrations simulated with stateof-the-art Chemistry and Transport Models (CTM). Hence, accurate representation of deposition velocities is crucial to improvements in the simulation of the surface sink flux of species, which is an important part of their atmospheric cycle. In addition, a better evaluation of this flux could lead to a better estimation of uncertainties in the emissions inventories, since errors on emissions and on deposition fluxes may average out in models.

MOCAGE (Modèle de Chimie Atmosphérique à Grande Echelle) is the multiscale three-dimensional CTM of Météo-France, covering scales from the regional to the planetary one, and extending from the surface up to the middle stratosphere (Peuch et al., 1999). The model comprises up to four levels of two-way nested domains, the parent global grid providing fully consistent boundary conditions to the inner grids. This original model setting allows us to cover a wide range of scientific applications, from the study of climate-chemistry interactions and global-scale redistributions of species (Cathala et al., 2003), to "chemical weather" forecasting, down to the regional scale (Dufour et al., 2004). During the ESCOMPTE campaign, field experiment to constrain models of atmospheric pollution and emission transport that took place in the South-East of France (Marseilles, Berre area) in June-July 2001, MOCAGE was used to help define the measurement strategy, and provided real-time forecasts to decide on the launching of Intensive Observing Periods (IOP) and to direct mobile observing means (aircrafts, vehicles, etc.) towards zones of potential interest (Cros et al., 2004). A companion paper focuses on 
overall model performance against the ESCOMPTE observational database, and results of several sensitivity studies (Dufour et al., 2004). The surface module of MOCAGE includes dry deposition of gaseous species and aerosols. To compute realistic time-dependent fluxes at the surface, a 2D interface (Michou and Peuch, 2002) between MOCAGE and ARPEGE (Courtier et al., 1991), the French operational numerical weather prediction model, was developed. Dry deposition of $\mathrm{O}_{3}$, sulfur dioxide, nitrogen-containing compounds, as well as of long-lived and short-lived organic compounds, was parameterized on the basis of Wesely (1989), using the "big-leaf" resistance approach. MOCAGE calculates dry deposition velocities from three in series resistances (aerodynamic, laminar, and surface), over the different MOCAGE domains with varying resolutions, generally from $2^{\circ}$ over the globe down to $0.08^{\circ}$ over zoom domains. A number of modifications were incorporated into the original surface resistance scheme, the main one being the formulation of the stomatal resistance that follows the Jarvis-type meteorological approach of Noilhan and Mahfouf (1996). This approach attempts to modify a minimum stomatal resistance defined a priori through external factors, such as moisture and radiation availability (see Section 2). Recently, this surface deposition module has been extended to consider particulate dry deposition (Nho-Kim et al., 2004).

We present in this study comparisons between MOCAGE simulations and observations of dry deposition velocity made over a range of Mediterranean ecosystems during ESCOMPTE, in May, June and July 2001. Contrasted episodes in terms of atmospheric chemistry were documented during the field campaign, covering the range of typical situations encountered in the region. Periods with very important photochemical production and accumulation of $\mathrm{O}_{3}$ alternated with situations of strong turbulence (generally driven by "Mistral" established Northerly winds) leading to large dry deposition sinks and cleansing of the lower atmospheric layers. Therefore, it is of particular importance that the uptake of $O_{3}$ at the surface be accurately simulated within this region. Furthermore, the Mediterranean region appears as a crucial region for photochemistry at European and even global scales (Lelieveld et al., 2002), with both high photochemical production and high deposition. Even though such parameterizations of dry deposition as the one we use within MOCAGE are "universal", in the sense that they aim to replicate actual physical and biological processes, they have often been developed and evaluated against measurements of velocities and of long-term and large-scale estimates of pollutant uptake over Northern America ecosystems. It is worthwhile to estimate how well the parameterization performs in the ESCOMPTE Mediterranean zone.

On top of the regional specificities, an original aspect of this study is that the model surface (e.g., Leaf Area Index LAI) or meteorological parameters have not been specifically tuned for these different comparisons, as is common for instance in box modeling. Surface parameters, as well as meteorological forcings, are taken directly from the ARPEGE model. Hence, comparisons really account for the actual model performances for regional modeling. It should be noted that discrepancies between modeled and observed deposition velocities are often large, typically as large as 30\% (Wesely and Hicks, 2000). Such differences can be due to a number of factors, which include inherent model and observational uncertainties, differences between observed and modeled meteorologies, and uncertainty in surface hydro-meteorological conditions, as for instance in soil moisture which is not yet observed on a routine operational basis. At short time- 
scales, other factors contribute to the variability (e.g., interactions between the plant and the atmosphere, physiological processes in the plant) which the big-leaf approach cannot account for. Hence, the high frequency variability will not be discussed further and we will focus on diurnal and synoptic evolutions.

After presenting some details on the deposition velocity parameterization used (Section 2), we mention briefly how the overall model performances in the Mediterranean region compare with data in the literature (Section 3). We present the ESCOMPTE dry deposition observation sites in Section 4. Then in Section 5 we discuss measurements and compare them with the corresponding model outputs; sensitivity tests further complete the analysis.

\section{Dry deposition parameterization}

The dry deposition flux of a pollutant $x$ in the atmospheric surface layer is often expressed as the product of its concentration $C_{x}$ and of its deposition velocity $V_{d x}$, with $V_{d x}$ being defined in terms of resistances (Wesely, 1989):

$$
F_{c x}=V_{d x} \times C_{x} \text { and } V_{d x}=\frac{1}{\left(R_{a}+R_{b x}+R_{c x}\right)}
$$

where $R_{a}$ is the aerodynamic resistance between the flux calculation level and the surface, identical for all substances, $R_{b x}$ is the quasi-laminar resistance, and $R_{c x}$ the bulk surface resistance. An account of the parameterizations used in MOCAGE for the different terms $R_{a}, R_{b x}$, and $R_{c x}$ appears in Michou and Peuch (2002). We present below an element of the parameterization which is not detailed in this previous paper, but is useful in the discussion of Section 5.

The stomatal resistance $R_{\text {stomx }}$ is a key term of the bulk surface resistance $R_{c x}$. It is proportional to the stomatal resistance to water vapor, $R_{\text {swat }} . R_{\text {swat }}$ was formulated in MOCAGE according to the ISBA (Interaction between Soil Biosphere and Atmosphere) surface scheme (Noilhan and Mahfouf, 1996), used both for operational numerical weather prediction and climate modeling. ISBA follows the Jarvis-type meteorological approach:

$$
R_{\text {stomx }}=R_{\text {swat }} \times \frac{D_{\mathrm{H}_{2} \mathrm{O}}}{D_{x}} \text { and } R_{\text {swat }}=\frac{R_{\text {smin }}}{L A I} \times \frac{F_{1}}{F_{2} F_{3} F_{4}}
$$

where $D_{x}$ is the molecular diffusivity of the gas $x, R_{\text {smin }}$ the minimum stomatal resistance, $F_{1}$ accounts for the photosynthetically active radiation (PAR) term, $F_{2}$ represents the stress related to the soil moisture, $F_{3}$ is the stomatal closure when the environment becomes drier (function of the vapor pressure deficit in the atmosphere), and $F_{4}$ is the effect of temperature. We recall below the $F_{2}$ formulation:

$$
F_{2}=\left\{\begin{array}{lll}
1 & w_{2}>w_{\mathrm{fc}} & w_{2}: \text { deep soil volumetric water content } \\
\frac{w_{2}-w_{\text {wilt }}}{w_{\mathrm{fc}}-w_{\text {wilt }}} & w_{\text {wilt }}<w_{2} \leq w_{\mathrm{fc}} & w_{\text {wilt }}: \text { wilting point volumetric water content } \\
10^{-5} & w_{2} \leq w_{\text {wilt }} & w_{\mathrm{fc}}: \text { field capacity volumetric water content }
\end{array}\right.
$$

The stomatal resistance is minimum when $R_{\text {swat }}$ is also minimum, which requires that, for a given $R_{\text {smin }}$ and LAI, the meteorological constraints are close to 1 . This is the case 
when the PAR is high, the soil moisture content is above its field capacity, and the air is close to saturation with a temperature of about $298 \mathrm{~K}$.

All low-level meteorological and surface forcing fields are taken from the ARPEGE or ALADIN (limited area version of the previous, providing an approximate resolution of 10 km over France and neighboring countries) operational analyses and short-term forecasts, available on a three-hourly basis at Météo-France. A cubic spline temporal interpolation is used to yield hourly forcings; hourly dry deposition velocities are computed within the surface module of MOCAGE for approximately 100 gaseous compounds, over the different model domains. Among other forcings provided by the meteorological models, soil moisture is calculated within ARPEGE and ALADIN from prognostic equations that distinguish surface and deep soil water contents (Giard and Bazile, 2000). The land use description within MOCAGE is the same as in ARPEGE and ALADIN. In particular, over the ESCOMPTE domain, a Météo-France dataset $\left(2-\mathrm{km}\right.$ mesh size interpolated to a $5^{\prime}$ resolution) provides a reliable forest mask, and an accurate description of the annual vegetation cycle (Champeaux et al., 1999). Look-up tables provide values for root depth, vegetation albedo, vegetation roughness length, minimum stomatal resistance, and monthly LAI values and vegetation fraction (percentage of soil covered by vegetation in a grid cell). The model $R_{\text {smin }}$ does not vary during the year eventhough field experiments revealed that it is indeed dependent on the phenological phase of the vegetation (Niyogi and Raman, 1997). For crops, ARPEGE/ALADIN typical values of $R_{\text {smin }}$ are $40 \mathrm{~s} \mathrm{~m}^{-1}\left(80 \mathrm{~s} \mathrm{~m}^{-1}\right.$ for Mediterranean crop and vineyard), of $z_{0} 0.15 \mathrm{~m}$, and of root depth $2 \mathrm{~m}$, while for temperate forests these typical values are respectively $150 \mathrm{~s} \mathrm{~m}^{-1}, 2 \mathrm{~m}$, and $3 \mathrm{~m}$.

\section{Seasonal variations in the Mediterranean region}

Even though we mainly focus on specific site and case comparisons, it is useful to consider briefly the typical model performances in the Mediterranean region over longer periods of time. We present in this paragraph a comparison of modeled and observed deposition velocities over an annual cycle at a Mediterranean site.

We selected one MOCAGE cell $\left(5.3^{\circ} \mathrm{E}, 44.1^{\circ} \mathrm{N}\right.$ from the $0.25^{\circ}$ model domain) within the ESCOMPTE domain, to compare with the observations of $\mathrm{O}_{3}$ deposition velocity of Pio et al. (2000). These observations were carried out during approximately 1 year over a grass field in Portugal under southern European climate conditions, by eddy correlation measurements. Fig. 1 shows the model outputs: there is a clear seasonal cycle for the daytime hours $(9,12$ and 15 UTC), while there is no such cycle for the night-time hours $(00$, 03, and 21 UTC), in agreement with the observations reported in Pio et al. (2000). Minimum mean model deposition velocities of $0.1 \mathrm{~cm} \mathrm{~s}^{-1}$ agree with the observations, while maximum ones are significantly higher, $1.18 \mathrm{~cm} \mathrm{~s}^{-1}$ vs. $0.55 \mathrm{~cm} \mathrm{~s}^{-1}$. We present in Section 5 various possible causes (other than measurement site specific features that could play a role in the error) for such a discrepancy. As in Pio et al. (2000), maximum values are observed in May and June, and correspond to the vegetation cycle with maximum stomatal activity before the senescence of the plant, during the hot summer. A smaller peak appears in autumn. Similar two peak-patterns are reported in $\mathrm{Wu}$ et al. (2003b) for a deciduous forest site in Pennsylvania, and a soybean field site in Tennessee. It is believed that the 


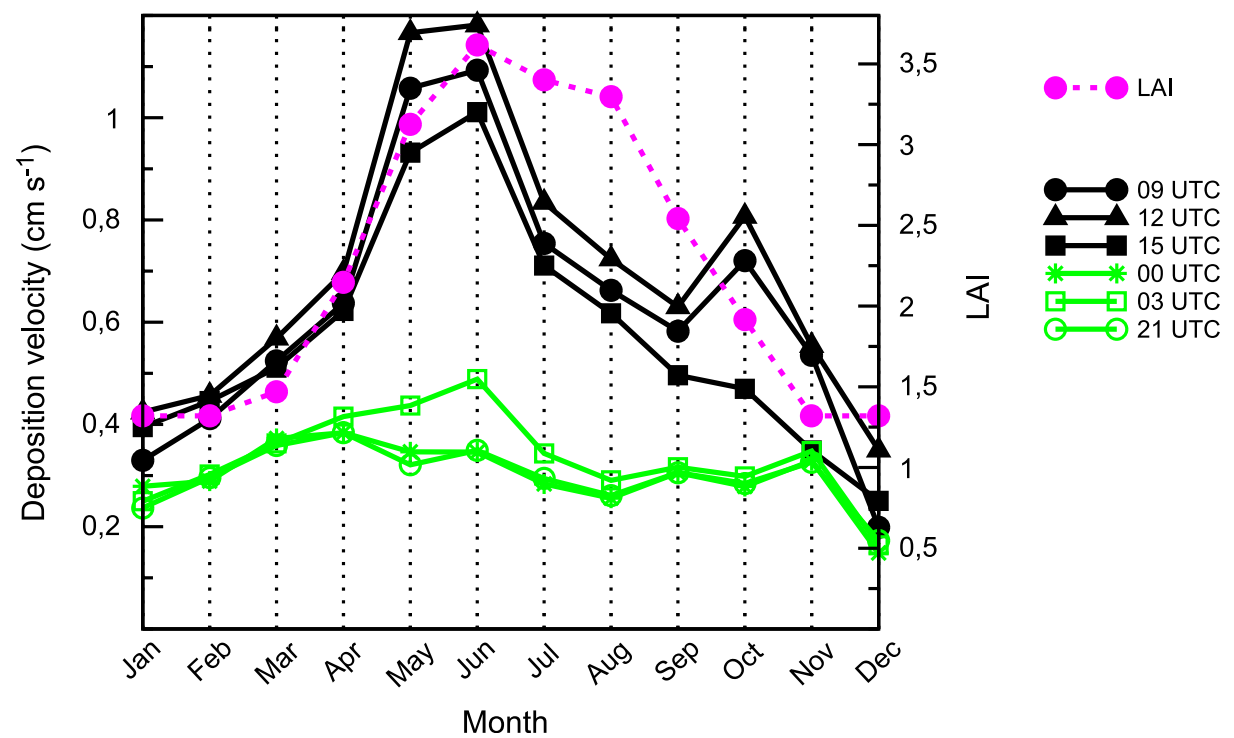

fall-off between the two peaks is due to drought, while the second peak is due to rainfall occurring late in the season that fills in the soil water reservoirs. We can note that introducing seasonal variations in the $R_{\text {smin }}$, as suggested in Pio et al. (2000), would certainly lead to better agreement between observations and model outputs. In conclusion, the model appears to capture nicely the diurnal and seasonal features in the deposition; the most challenging part of the comparison is for the summer months, for which deposition is highest and the model is overestimating the maximum values. These conditions prevailed during ESCOMPTE and we will investigate them in Section 5.

\section{Site description}

Data collected at the sites instrumented during ESCOMPTE for trace gas flux measurements were used in this study. These four sites were chosen for their representativity of the main land use types of the ESCOMPTE domain, and comprised a maize field, a Mediterranean forest, a shrub-land area, and an almost bare soil. A summary of the site descriptions can be found in Table 1. A short description of both instrumental and environmental conditions follows.

Table 1

Site summary

\begin{tabular}{llll}
\hline Site & Coordinates & Vegetation cover & Operation period \\
\hline Meyrargues & $43^{\circ} 39^{\prime} \mathrm{N}, 5^{\circ} 32^{\prime} \mathrm{E}, 195 \mathrm{~m}$ & Maize & 12 to 28 June 2001 \\
Montmeyan & $43^{\circ} 39^{\prime} \mathrm{N}, 6^{\circ} 05^{\prime} \mathrm{E}, 525 \mathrm{~m}$ & Mediterranean forest & 10 to 26 June 2001 \\
La Barben & $43^{\circ} 35^{\prime} \mathrm{N}, 5^{\circ} 15^{\prime} \mathrm{E}, 165 \mathrm{~m}$ & Mediterranean shrub & 29 June to 13 July 2001 \\
La Crau & $43^{\circ} 34^{\prime} \mathrm{N}, 4^{\circ} 49^{\prime} \mathrm{E}, 10 \mathrm{~m}$ & Almost bare soil & 20 April to 31 May 2001 $\left(\mathrm{O}_{3}\right)$ \\
& & & 15 May to 7 June 2001 $\left(\mathrm{NO}_{x}\right)$ \\
\hline
\end{tabular}




\subsection{Meyrargues: maize site}

The maize field was located $30 \mathrm{~km}$ North of Marseilles $\left(43^{\circ} 39^{\prime} \mathrm{N}, 5^{\circ} 32^{\prime} \mathrm{E}\right.$, altitude: $195 \mathrm{~m}$ ) over an area of $13 \mathrm{ha}$. The fetch exceeded $200 \mathrm{~m}$ in all directions apart from the South, where the field boundary was only $100 \mathrm{~m}$ from the instruments. The surrounding areas were crop-land in a flat terrain, the Durance valley. During the period of observations, the crop was growing fast, with an estimated LAI varying from 0.8 to 2.8 , and a roughness length from 0.05 to $0.12 \mathrm{~m}$.

Two major instrument systems, fast and slow response instruments, were installed and managed at this site by the "Environnement et Grandes Cultures" team of INRA (Institut National de la Recherche Agronomique), yielding to the evaluation of $\mathrm{O}_{3}$ fluxes with both eddy correlation and gradient methods. Additional fluxes, such as $\mathrm{H}_{2} \mathrm{O}$ fluxes, were also measured. A standard meteorological station, installed on the site for the experiment, provided measurements of solar radiation, air temperature, humidity, pressure, precipitation, and wind direction. In addition, vegetation height and LAI, heat flux to the ground, soil humidity and temperature, as well as parameters to characterize the soil texture and composition were measured.

We present in this study results from the eddy correlation measurements only. Fluxes were estimated from the covariance between the vertical wind speed measured with a 3D sonic anemometer (solent 1012R2, Gill Instruments, UK), and the concentration measured either with a fast-response $\mathrm{O}_{3}$ chemiluminescent analyser (OS-G-2, Güsten, 1992), or a fast response $\mathrm{CO}_{2} / \mathrm{H}_{2} \mathrm{O}$ infrared absorption spectrometer (LI 6262, LI-COR, USA). All turbulent data were sampled at $21 \mathrm{~Hz}$. Flux integration was performed over $15 \mathrm{~min}$. All data were measured at $2.8 \mathrm{~m}$ above ground. The calibration of the $\mathrm{O}_{3}$ OS-G-2 analyser was continuously checked against the slow-response $\mathrm{O}_{3}$ monitor (model 41M, UV photometric, Environnement SA, Poissy, France; sensitivity: 1 ppbv).

Measurements were carried out from 12 to 28 June 2001, covering IOP 1 and $2 \mathrm{a} / 2 \mathrm{~b}$, during a rain-free period with mostly clear skies, elevated temperatures and low humidity during the day. A period of established North-westerly wind (so-called Mistral) started in the afternoon of 16 June and ended after noon on 18 June. During that period, the observed wind velocity at night was higher than $3 \mathrm{~m} \mathrm{~s}^{-1}$, in contrast with values of all other nights when calm winds were observed, while mean day-time values were about $7 \mathrm{~m} \mathrm{~s}^{-1}$. Humidity of the soil decreased slowly throughout the period until a field irrigation on 27 June.

\subsection{Montmeyan: Mediterranean forest site}

The land cover at Montmeyan $\left(43^{\circ} 39^{\prime} \mathrm{N}, 6^{\circ} 05^{\prime} \mathrm{E}\right.$, altitude: $\left.525 \mathrm{~m}\right)$ was typical of a Mediterranean forest, made up at 95\% of Quercus Pubescens, with a mean height of $12 \mathrm{~m}$, and an under-layer relatively dense and homogeneous (estimated LAI: 2.3, and roughness length: $0.77 \mathrm{~m}$ ).

An instrumented tower, $14 \mathrm{~m}$ high, was installed and managed by the Laboratoire d'Aérologie (LA). A number of parameters were measured to calibrate the fast sensors and to characterize the meteorological conditions of the experiment, including pressure, wind, temperature and humidity profiles, net and solar radiation. The vertical wind speed and $\mathrm{O}_{3}$ 
concentration fluctuations were measured at the top of the tower with fast response instruments, a sonic anemometer and a chemiluminescent analyser, respectively (same systems as the ones used at the Meyrargues site). In addition, fluxes of sensible heat, latent heat, and $\mathrm{CO}_{2}$ were sensed, as well as $\mathrm{NO}_{x}, \mathrm{SO}_{2}$, and aerosol mean concentrations, and temperature profiles in the soil. Soil humidity was not estimated. Turbulent data were sampled at $64 \mathrm{~Hz}$, and averaged over half-hour periods. Measurements were carried out from 10 to 26 June 2001 during a period of typical summer Mediterranean weather, with dry, mostly cloud-free days with elevated temperatures. The area, mainly flat, was under the influence of two wind regimes. There were either South-Easterly winds or generally stronger North-Westerly winds. Further details can be found in Bouchou (2004).

\subsection{La Barben: shrub-land site}

Measurements of $\mathrm{O}_{3}$ fluxes above Mediterranean shrub-land (La Barben, $43^{\circ} 35^{\prime} \mathrm{N}$, $5^{\circ} 15^{\prime} \mathrm{E}$, altitude $65 \mathrm{~m}$ ), mostly composed of Quercus coccifera, with a mean height of $0.5 \mathrm{~m}$ (estimated roughness length: $0.03 \mathrm{~m}$ ), have been carried out from 29 June to 13 July 2001 by the eddy correlation method. The instrumented tower, $8 \mathrm{~m}$ high, identical to the one described in Section 4.2, was managed by LA. Again, at this site, meteorological conditions consisted mostly of dry cloud-free weather, with maximum daily temperatures around $303 \mathrm{~K}$, and low air humidity during the day (40\% relative humidity). Further details can be found in Bouchou (2004).

\subsection{La Crau: bare soil site}

This experimental site $\left(43^{\circ} 34^{\prime} \mathrm{N}, 4^{\circ} 49^{\prime} \mathrm{E}\right.$, altitude: $\left.10 \mathrm{~m}\right)$ was located in the semi-arid part of the La Crau plain which covers an area of 11,500 ha, and consists of a totally flat, uniform, almost bare soil. The fetch was large in all directions, at least $1 \mathrm{~km}$, and the estimated roughness length was $1.54 \mathrm{~cm}$. Local emissions were low, but the very important industrial complex of Fos-Berre was located just $20 \mathrm{~km}$ south. Observations of $\mathrm{O}_{3}$ fluxes were made by LA between 20 April and 31 May 2001, actually before the beginning of the field campaign, using an instrumentation on a mast (height $8 \mathrm{~m}$ ) identical to the one described in Section 4.2, and the eddy correlation technique. Local meteorological parameters (see list in Section 4.2) have also been measured at the site from the mast (further details can be found in Bouchou, 2004). Observations of $\mathrm{NO}_{x}$ (nitric oxide $\mathrm{NO}+$ nitrogen dioxide $\mathrm{NO}_{2}$ ) fluxes were made between 15 May and 7 June 2001, with the Relaxed Eddy Accumulation (REA) method, also by LA from a separate mast (height $6 \mathrm{~m}$ ). This REA method is an evolution of the eddy accumulation method, and has received increasing attention over the past few years as it determines trace gas fluxes combining the use of a fast response wind anemometer and of a slow response trace gas analyser (see description of the REA method in Pryor et al., 2002 and in Fotiadi et al., in press-a). This system allows estimation of nitrogen oxide fluxes at the scale of a field $\left(\mathrm{km}^{2}\right)$. The instrumental device used is described in details in Fotiadi (2003): in summary, it was a prototype system developed at LA that included a 3D sonic anemometer (Young TM, model 81000 ) and a chemiluminescent $\mathrm{NO}-\mathrm{NO}_{2}-\mathrm{NO}_{x}$ analyser (model 42S, Thermo-Environ-

mental Instruments $\mathrm{TM}$ ). $\mathrm{NO}$ and $\mathrm{NO}_{2}$ concentrations were obtained differentially with a 
molybdenum $\mathrm{NO}_{2}$ to $\mathrm{NO}$ converter $\left(\right.$ at $325^{\circ} \mathrm{C}$ ). This converter is known to be non-specific to the determination of $\mathrm{NO}_{2}$, as it also converts other reactive nitrogen compounds to $\mathrm{NO}$ (Kirkman et al. (2002), and references therein). The experimental conditions at La Crau prevented us from identifying specific nitrogen compounds that were, or were not, reduced by the molybdenum converter. Quality control criteria described in Fotiadi et al. (in press-b) have been applied to the measured fluxes and included dynamic, REA operation, and chemical criteria: rejected samples mainly corresponded to neutral, stable nocturnal, and some high convective unstability cases that occurred during the development of the atmospheric boundary layer.

Two main wind regimes characterized the meteorological conditions at La Crau: the first one with strong North-north-westerly winds (Mistral, mean velocity of $9 \mathrm{~m} \mathrm{~s}^{-1}$ with peaks up to $18 \mathrm{~m} \mathrm{~s}^{-1}$ ) that brought dry air to the area; the second one with lighter and more humid winds from the South-south-east which was reinforced by the sea-breeze circulation. During most of the periods of observation, the sky was clear or only partially cloudy. Further details on the meteorological conditions can be found in Fotiadi (2003).

\section{Observations and model evaluation}

\subsection{Ozone deposition velocities over a maize field}

We computed hourly averages over the period of observations, of both modeled and observed meteorological conditions, and we present in Table 2 some typical parameters: the daily maximum of the incoming solar radiation at the surface $\left(R_{\mathrm{g}}\right)$; the daily minimum and maximum of the surface temperature $\left(T_{\text {surf }}\right)$, which is one of the surface variables in ARPEGE/ALADIN; a night and a day value of the friction velocity $\left(u_{*}\right)$, parameterized as in Michou and Peuch (2002), the night value being the average of the 00, 03 and 21 UTC values, and the day value the average of the 09, 12 and 15 UTC values (note that at all sites the solar time and the UTC time are the same); we also present the soil volumetric humidity $\left(\mathrm{HU}_{\text {soil }}\right)$, the model one being the humidity over the soil-root depth (see Section 2 for typical model root depths).

Table 2

Modeled and observed meteorological parameters at the ESCOMPTE sites

\begin{tabular}{lllll}
\hline & $R_{\mathrm{g}}\left[\mathrm{W} \mathrm{m}^{-2}\right]$ & $T_{\text {surf }}[\mathrm{K}] \mathrm{min}-\mathrm{max}$ & $u *\left[\mathrm{~m} \mathrm{~s}^{-1}\right]$ night-day & $\mathrm{HU}_{\text {soil }}\left[\mathrm{m}^{3} \mathrm{~m}^{-3}\right]$ \\
\hline Obs Meyrargues & 945 & $288-312$ & $0.11-0.42$ & 0.22 \\
Mod Meyrargues & 949 & $286-302$ & $0.21-0.46$ & 0.26 \\
Obs Montmeyan & 922 & $286-314$ & $0.27-0.62$ & 0.21 \\
Mod Montmeyan & 907 & $287-303$ & $0.43-0.77$ & \\
Obs La Barben & 821 & $291-328$ & $0.20-0.43$ & 0.19 \\
Mod La Barben & 875 & $292-310$ & $0.26-0.57$ & 0.03 \\
Obs La Crau $\left(\mathrm{O}_{3}\right)$ & 717 & $280-299$ & $0.25-0.39$ & 0.18 \\
Mod La Crau $\left(\mathrm{O}_{3}\right)$ & 758 & $285-300$ & $0.29-0.44$ & \\
\hline
\end{tabular}

Values are hourly averages over the period of observations. $R_{\mathrm{g}}$ : maximum of incoming solar radiation at the surface; $T_{\text {surf: }}$ minimum-maximum of surface temperature; $u_{*}$ : friction velocity, night-day values (see text); $\mathrm{HU}_{\text {soil: }}$ volume of water per volume of soil. 
At the maize site, the model appeared to reproduce well the maximum $R_{\mathrm{g}}$, the minimum $T_{\text {surf }}$, and the $\mathrm{HU}_{\text {soil }}$ while there were discrepancies between the observed and modeled night $u *\left(0.11 \mathrm{~m} \mathrm{~s}^{-1}\right.$ vs. $\left.0.21 \mathrm{~m} \mathrm{~s}^{-1}\right)$. Thus, the dynamic model turbulence was higher than observed during the night. Furthermore, the model underestimated the maximum surface temperature, very sensitive to the local land cover conditions ( $302 \mathrm{~K}$ vs. $312 \mathrm{~K}$ ).

Observed $\mathrm{O}_{3}$ deposition velocities varied from 0 to $0.80 \mathrm{~cm} \mathrm{~s}^{-1}$, with a mean minimum of $0.05 \mathrm{~cm} \mathrm{~s}^{-1}$, and a mean maximum of $0.50 \mathrm{~cm} \mathrm{~s}^{-1}$. Nocturnal values were most of the time close to 0 , except during a windy Mistral period (17-18 June). The average diurnal cycle was quite symmetrical, with deposition velocities increasing from 5 to 10 UTC, then remaining fairly constant until 15 UTC (see Table 3 and Fig. 2(b)). During strong wind conditions, $\mathrm{O}_{3}$ deposition velocity was mostly controlled by the dynamic turbulence (correlation coefficient between $V_{\mathrm{dO}_{3}}$ and $u *$ of 0.87 ), while during day-time observations revealed that a significant part of the $\mathrm{O}_{3}$ deposition was due to non-stomatal uptake.

We compared hourly dry deposition velocities of $\mathrm{O}_{3}$, observed from 8 to 28 June, to the corresponding $0.08^{\circ}$ resolution MOCAGE cell values. Though modeled and observed velocities appear quite reasonably correlated ( $r=0.67$, see Table 3$)$, MOCAGE systematically overpredicts deposition velocities, both during the night and the day; the mean bias is of $0.26 \mathrm{~cm} \mathrm{~s}^{-1}$ and the centered pattern root mean square error (RMSE) of $0.21 \mathrm{~cm} \mathrm{~s}^{-1}$. This centered RMSE is defined as the RMSE of the observed and modeled fields from which respective means have been subtracted (see formula in Table 3 title). There is also a greater temporal variability in the model, with a standard deviation of $0.28 \mathrm{~cm} \mathrm{~s}^{-1}$ against the observed value of $0.19 \mathrm{~cm} \mathrm{~s}^{-1}$.

Observed and modeled $\mathrm{O}_{3}$ depositions at Meyrargues are presented in Fig. 2. $\mathrm{O}_{3}$ deposition velocities over crops can be quite different depending on the type of crop but observations higher than $1 \mathrm{~cm} \mathrm{~s}^{-1}$ have seldom been reported while our simulations can be on occasions in excess of this value. Exceptionally high values of $1.5 \mathrm{~cm} \mathrm{~s}^{-1}$ were observed over soybean fields in North Carolina (Wesely and Hicks, 2000) and in Tennessee (Niyogi et al., 2003). Cooter and Schwede (2000) outlines the important role of the value of the minimum stomatal resistance $R_{\text {smin }}$ to the estimation of the deposition velocity of $\mathrm{O}_{3}$ in particular, but there is substantial disagreement between atmospheric scientists and plant modelers concerning appropriate values of $R_{\mathrm{smin}}$ : for instance, in Bougeault et al. (1991) and in Masson et al. (2003) $R_{\mathrm{smin}}=40 \mathrm{~s} \mathrm{~m}^{-1}$ for crops in general, in Calvet et al. (1998)

Table 3

Statistics on deposition velocity $\left(\mathrm{cm} \mathrm{s}^{-1}\right)$

\begin{tabular}{llllllrrr}
\hline Site & $n$ & $\overline{o b s}$ & $\overline{m o d}$ & $\sigma_{\text {obs }}$ & $\sigma_{\text {mod }}$ & \multicolumn{1}{r}{$r$} & Bias & C RMSE \\
\hline Meyrargues & 308 & 0.27 & 0.53 & 0.19 & 0.28 & 0.67 & 0.26 & 0.21 \\
Montmeyan & 248 & 0.26 & 0.24 & 0.20 & 0.14 & 0.30 & -0.02 & 0.21 \\
La Barben & 157 & 0.19 & 0.33 & 0.14 & 0.08 & -0.28 & 0.14 & 0.18 \\
La Crau $O_{3}$ & 650 & 0.21 & 0.51 & 0.13 & 0.20 & 0.36 & 0.30 & 0.19 \\
La Crau $\mathrm{NO}_{x}, \mathrm{HNO}_{3}$ & 280 & 1.21 & 1.81 & 1.30 & 0.90 & 0.39 & 0.60 & 1.26 \\
\hline
\end{tabular}

$n$ : number of hourly observations; $\overline{o b s}$ : average observed deposition velocity; $\overline{m o d}$ : average modeled deposition velocity; $\sigma_{\mathrm{obs}}$ : standard deviation of observations; $\sigma_{\text {mod }}$ : standard deviation of model outputs; $r$ : correlation coefficient; bias: $\frac{1}{n} \sum_{k=1}^{n}\left(\bmod _{k}-o b s_{k}\right)$; C RMSE: centered pattern root mean square error: $\left\{\frac{1}{n} \sum_{k=1}^{n}\left[\left(\bmod _{k}-\overline{\bmod }\right)-\left(o b s_{k}-\overline{o b s}\right)\right]^{2}\right\}^{\frac{1}{2}}$. 
(a)

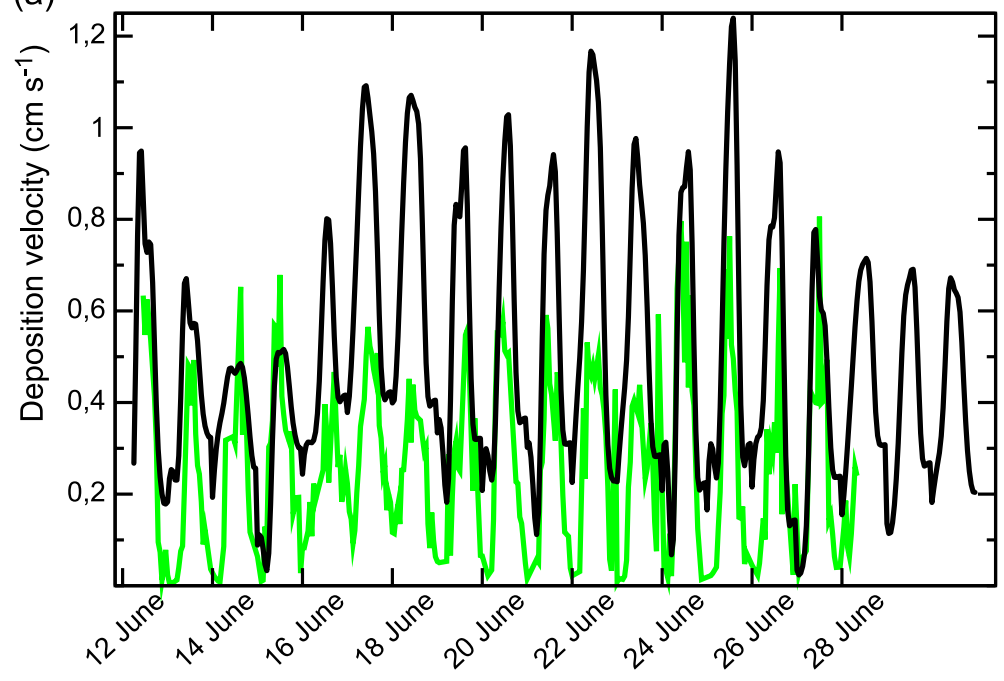

(b)

Days

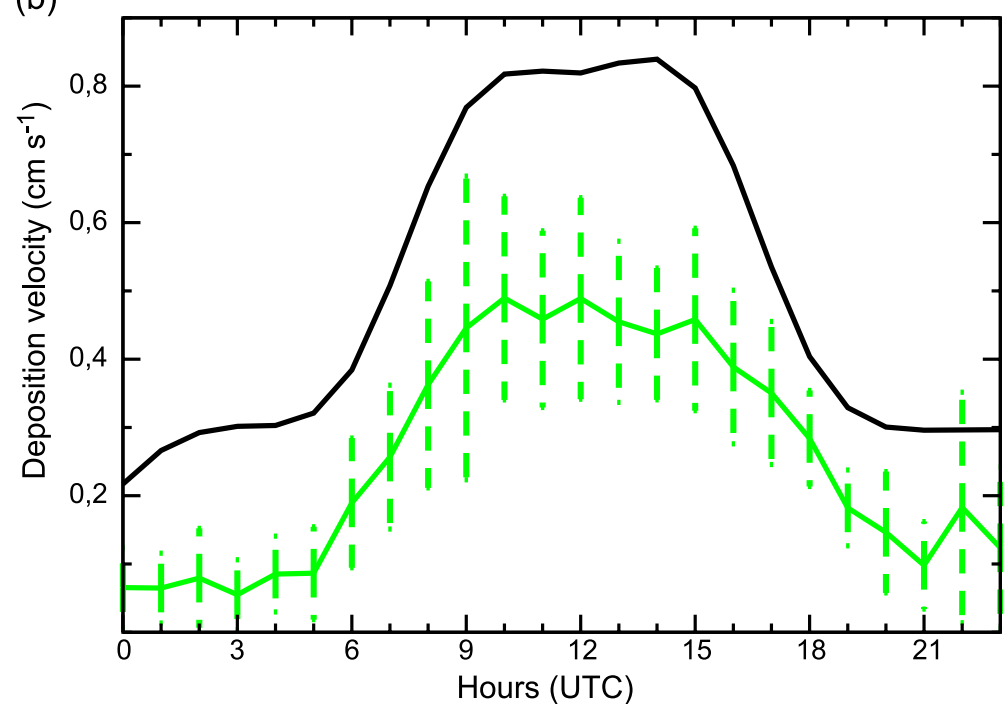

Fig. 2. $\mathrm{O}_{3}$ deposition velocities over a maize field (Meyrargues) from 12 to 28 June 2001. (a) Time series of hourly values, observed (grey) and calculated by MOCAGE at $0.08^{\circ}$ resolution (black) with $z_{0}=0.25 \mathrm{~m}$ and $R_{\text {smin }}=58 \mathrm{~s} \mathrm{~m}^{-1}$. (b) Average diurnal cycles for the observations (grey) and the model (black). Dashed lines represent the standard deviations of the observations.

$R_{\mathrm{smin}}=130 \mathrm{~s} \mathrm{~m}^{-1}$ for maize, and in Zhang et al. (2002) $R_{\mathrm{smin}}=250 \mathrm{~s} \mathrm{~m}^{-1}$ also for maize. We therefore conducted two additional simulations, differing only by the value of $R_{\mathrm{smin}}$ in the calculation of $R_{\text {swat, }}$, despite the known fact that other input variables are correlated to the $R_{\text {smin }}$ (e.g., latent heat, sensible heat, surface temperature). As a matter of consequence, these sensitivity tests should be regarded more qualitatively than quantitatively, displaying 
only our model sensitivity to one of the parameters. $R_{\text {smin }}$ was changed from the initial model value of $58 \mathrm{~s} \mathrm{~m}^{-1}$ (the model grid cell is mainly composed of crops), to 100 and 250 $\mathrm{s} \mathrm{m}^{-1}$, the meteorological and soil hydrological forcings remaining unchanged. Peak deposition velocities are remarkably smaller when $R_{\text {smin }}$ is set to $250 \mathrm{~s} \mathrm{~m}^{-1}$, close to the observed values, with differences between deposition velocities when $R_{\mathrm{smin}}=58 \mathrm{~s} \mathrm{~m}^{-1}$ and $R_{\text {smin }}=250 \mathrm{~s} \mathrm{~m}^{-1}$ reaching $0.55 \mathrm{~cm} \mathrm{~s}^{-1}$ (see Fig. 3(a)).

Modeled velocities are generally too high during the night (see Fig. 2), though they have realistic very low values $\left(<0.1 \mathrm{~cm} \mathrm{~s}^{-1}\right)$ on certain dates as on 15,24 and 27 June. This bias has been reported in the literature: Wesely and Hicks (2000) indicates that the aerodynamic resistance $R_{\mathrm{a}}$, that controls deposition during the night, cannot be easily modeled with conventional micrometeorological approaches in a very stable near surface atmospheric conditions prevailing at night. It should be noted also that both measurements of turbulence and of $\mathrm{O}_{3}$ concentrations are more problematic during the night: the night-time turbulence is more intermittent, and low levels of $\mathrm{O}_{3}$ can approach the detection level of the analyser. Hence, uncertainties on measured deposition velocities are larger during the night. As our modeled friction velocity is in general too high, both during day and night hours (see Table 2), we looked at the impact of changes in the roughness length $\left(z_{0}\right)$, reducing it from $0.25 \mathrm{~m}$ (model initial value) to $0.08 \mathrm{~m}$ (mean observed $z_{0}$ ). As in Ganzeveld et al. (1998), we assumed that this change in $z_{0}$ did not affect the wind speed at the reference height $(20 \mathrm{~m})$, nor did it change the temperature gradient which was mainly determined by the surface cover and not the surface roughness. The stability described by the Richardson number has thus not been modified in this simulation. Fig. 3(b) reveals a noticeable reduction of the deposition velocity for all hours of the day, improving the performances of the model. To finish on deposition at night, we point out higher night deposition velocities on 17 and 18 June, both modeled and observed, that coincide with the unstable boundary layer conditions of the Mistral period described in Section 4.1.

In complement to the sensitivity tests, we calculated dry deposition velocities with the dry deposition code, and meteorological, surface and soil observations used as input to the code. The dry deposition code was not altered in this modeling exercise. Various simulations underlined the following issues: model deposition velocities were in better agreement with observations when we took into account measurements of the LAI. During the period of observations, the maize was growing fast, and the LAI, estimated every other day, increased steadily from 0.8 to 2.8 . Considering the stomatal pathway as the only pathway to the uptake of $\mathrm{O}_{3}$ by the surface $\left(R_{\mathrm{cO}_{3}}=R_{\mathrm{stomO}_{3}}\right.$, with $R_{\text {smin }}$ set to $100 \mathrm{~s} \mathrm{~m}^{-1}$ and $F_{1}, F_{3}, F_{4}$ calculated with the observed meteorology), we obtained correct daily maxima for a number of days, but overestimations of this daily maximum for other days. These overestimations could be due to the fact that our model has no stomatal closure linked to air humidity deficit for crops (the $F_{3}$ factor in Eq. (2) is set to 1). Observations of deposition velocity of $\mathrm{O}_{3}$ and relative humidity at Meyrargues indicated that the daily maximum of deposition velocity was lower when the air humidity was lower. A personal communication from J.C. Calvet confirmed that the $F_{3}$ parameterization of our model should be changed for crops. Again with the hypothesis $R_{\mathrm{cO}_{3}}=R_{\mathrm{stomO}_{3}}$, we obtained too low deposition velocities during the nights with turbulence, as our model closes all stomata when there is no solar radiation $\left(R_{\text {swat }}\right.$ is then set to $\left.5000 \mathrm{~s} \mathrm{~m}^{-1}\right)$. This confirms the 
(a)

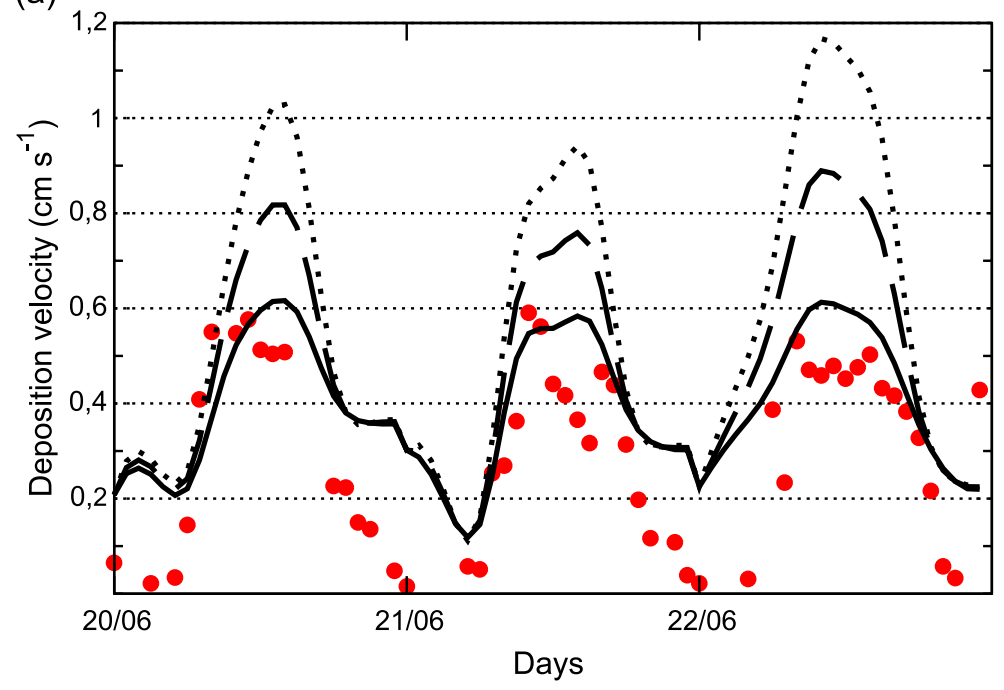

(b)

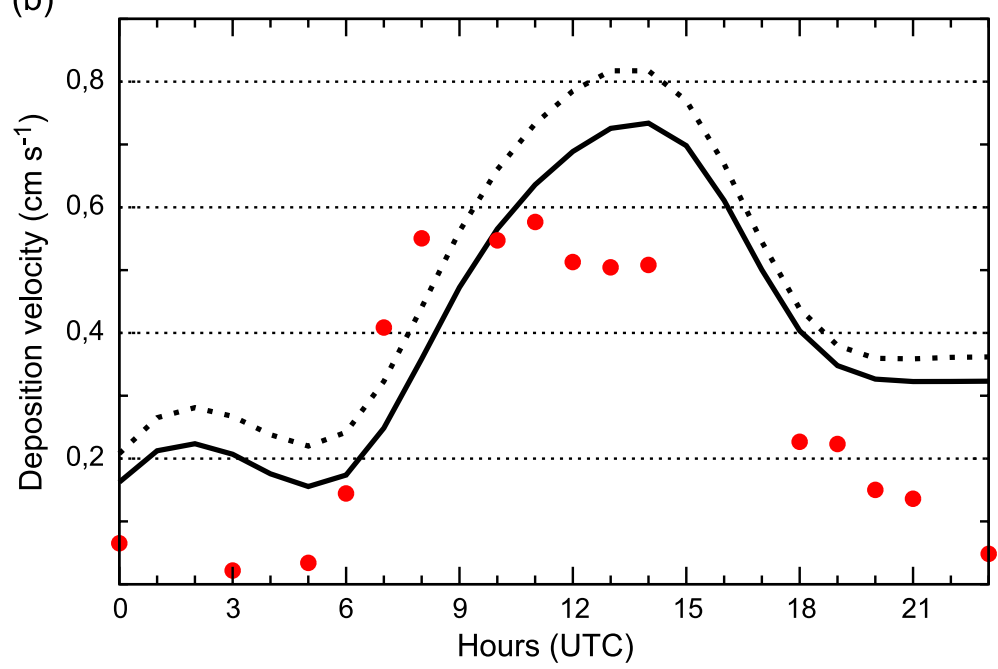

Fig. 3. (a) Sensitivity of the $\mathrm{O}_{3}$ deposition velocity over a maize field to the $R_{\mathrm{smin}}: R_{\mathrm{smin}}=58 \mathrm{~s} \mathrm{~m}^{-1}$ (dotted line), $R_{\mathrm{smin}}=100 \mathrm{~s} \mathrm{~m}^{-1}$ (dashed line), $R_{\mathrm{smin}}=250 \mathrm{~s} \mathrm{~m}^{-1}$ (solid line), and observations (dots), during 20-22 June 2001. $z_{0}$ was set to $0.25 \mathrm{~m}$ for this experiment. (b) Sensibility to the roughness length $z_{0}$ with $R_{\text {smin }}$ set to $100 \mathrm{~s} \mathrm{~m}^{-1}$, $z_{0}=0.25 \mathrm{~m}$ (dotted line), $z_{0}=0.08 \mathrm{~m}$ (solid line), and observations (dots) for 20 June 2001 .

importance of the non-stomatal uptake. Zhang et al. (2002) found that it increased with increasing dynamic turbulence. Finally, simulations with observed soil water content produced too low deposition velocities (average daily maximum lower than $0.2 \mathrm{~cm} \mathrm{~s}^{-1}$ ) until 27 June when the field was irrigated. We calculated the wilting point and field capacity volumetric water contents from the percentage of silt observed and formulations 
of our code (Noilhan and Mahfouf, 1996). Observed soil humidity was close to the wilting point during most of the period, and this simulated large stomatal closure. Several explanations can contribute to explain the differences between the simulations and the observations: representativity of the observations of the soil humidity, made over the first $15 \mathrm{~cm}$ of the soil, can probably be questioned. NO was emitted by this cultivated soil, and chemical reactions within the vegetation may have biased the observations of dry deposition. At last, non-stomatal uptake, such as uptake by the soil, may have contributed to a certain extent to the dry deposition of $\mathrm{O}_{3}$ during day light hours.

\subsection{Ozone deposition velocities over a Mediterranean forest}

The model appeared to simulate fairly accurately the maximum $R_{\mathrm{g}}$ and the minimum $T_{\text {surf }}$, while it underestimated the maximum $T_{\text {surf }}$, and it overestimated $u *$, both during the night and the day (see Table 2). Without such discrepancies, the model $\mathrm{O}_{3}$ deposition velocity could be lower, both during the night (impact of $u *$ ), and during the day (more stomatal closure with higher temperatures). Similar comments apply to the meteorological observations of the shrub-land site (Section 5.3).

Although the average and standard deviation of the observed deposition velocities were similar to those at the maize site (see Table 3), the striking feature in this data set is the asymmetry of the average diurnal cycle, with a peak very early in the morning (6 UTC or local solar time, see Fig. 4 (c)). Peaks at mid-morning hours (8 or 9 local solar time) have been reported in previous studies (e.g. Finkelstein et al., 2000, and references therein), and it has been suggested that the stomata of some plants are more sensitive to blue light, and open very early in the predawn hours. In our case, deposition velocities started to increase between 3 and 4 UTC, and increased steeply until 6 UTC, when they starting falling back quite regularly to their nocturnal values. The increase in deposition velocity may also be due to increased surface moisture that impacts on the surface chemistry. Lamaud et al. (2002) observed that surface wetness associated with dew significantly enhanced ozone deposition to a pine forest in France (Les Landes), during the night as well as in the morning. In our case, the surface wetness would have been caused by dew, as the period of observations was rain free (see Section 4.2). However, identification of dew on forest leaves appeared quite problematic. Clearly, further studies on dry deposition in nocturnal or surface wetted conditions are needed. As for the decrease in observed deposition velocities during day hours, it may be linked to particularly early and progressive closure of stomata during the day that seems quite specific to the Mediterranean forest and shrubland observed during summer months in ESCOMPTE.

Fig. 4 (a) shows the comparison between the hourly observations and the outputs of the $0.08^{\circ}$ resolution MOCAGE cell containing the site, obtained with the meteorological conditions simulated by ARPEGE.

Fig. 4. $\mathrm{O}_{3}$ deposition velocities over a Mediterranean forest (Montmeyan) in June 2001. (a) Time series of hourly deposition velocity; observed (grey) and calculated by MOCAGE at $0.08^{\circ}$ resolution (black). (b) Corresponding resistance terms calculated by MOCAGE; aerodynamic (solid black line), quasi-laminar (solid grey line), surface (dotted line). (c) Average diurnal cycles of $\mathrm{O}_{3}$ deposition velocity over the period of observations (10-26 June 2001); model (black), observations (grey, in dashed lines: standard deviations). 
(a)
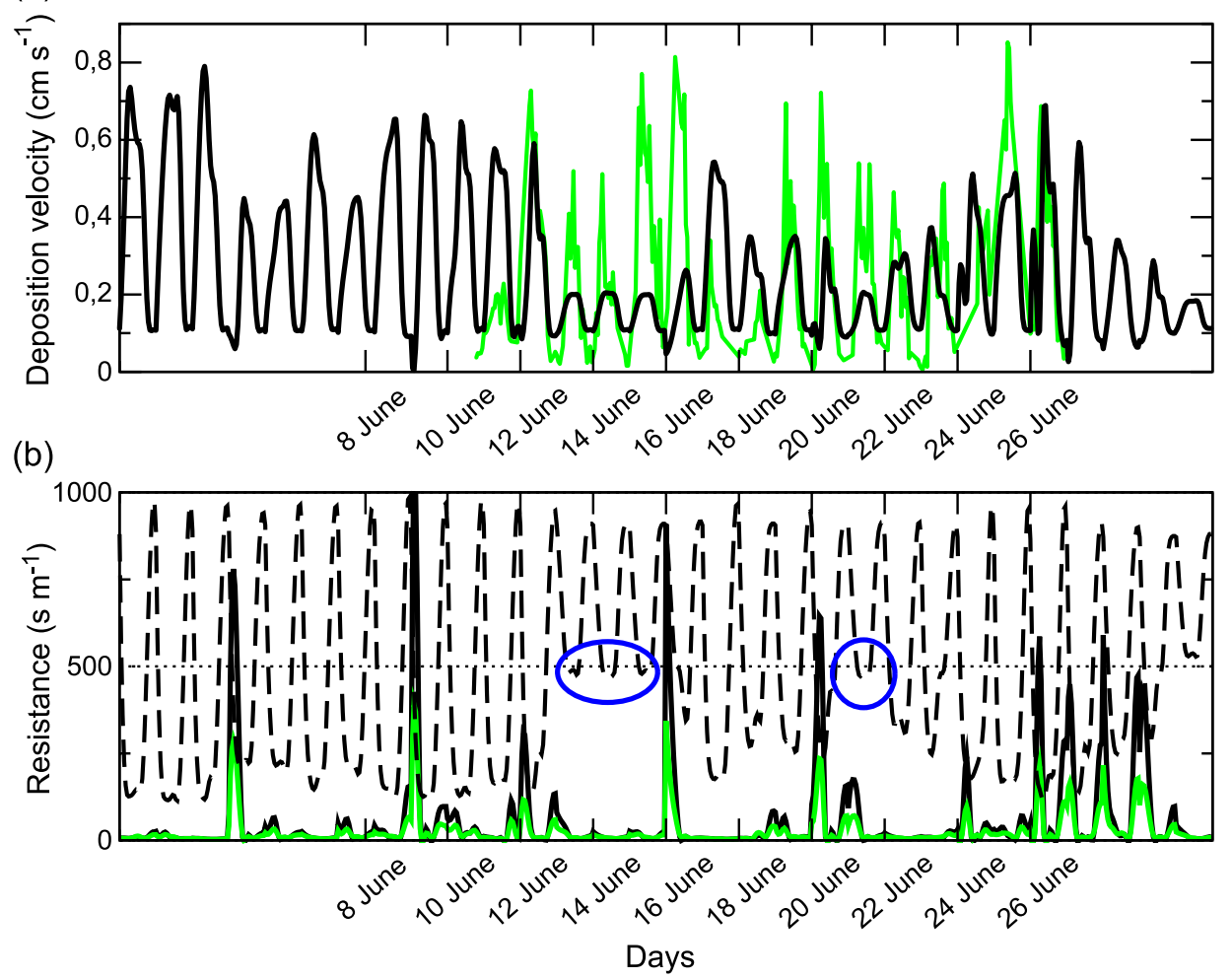

(c)

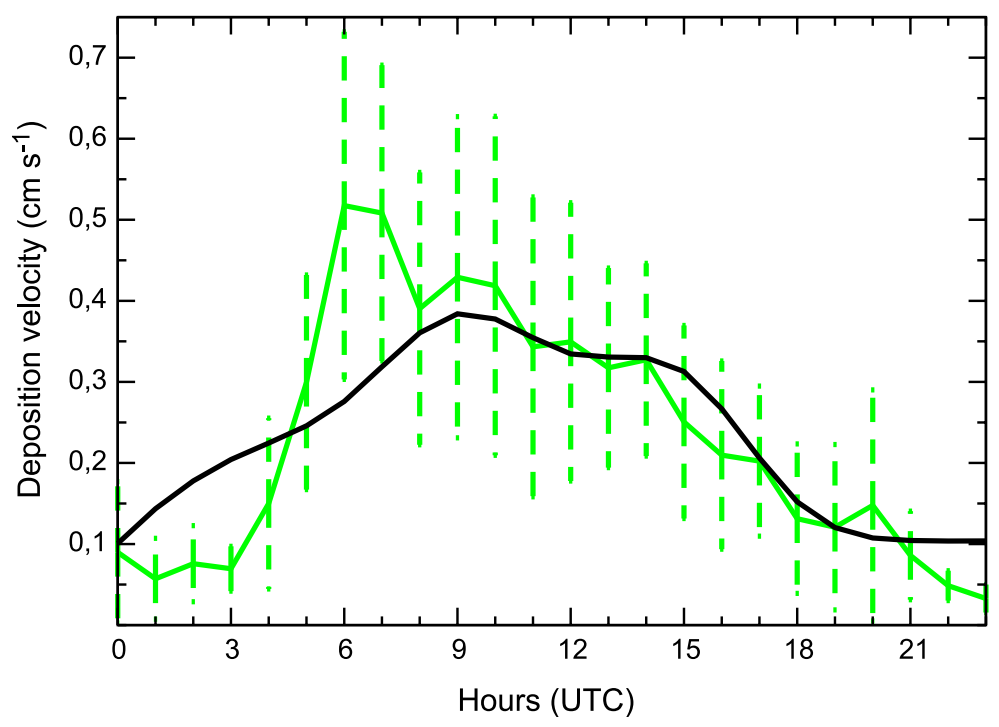


Observed and modeled velocities appear to be poorly correlated over the period of observations ( $r=0.30$, see Table 3$)$ : firstly, there is often a temporal lag between observations and model values, with a diurnal peak for the model around 9 UTC (see Fig. 4(c)); this delay in predicting the daily maximum has been reported in other model evaluations. Wu et al. (2003b) presents a comparison of several dry deposition models, including Wesely (1989), evaluated against data from six experimental fields in the USA: a lag of about three hours (observed peaks in mid morning at 8:00 or 9:00 local solar time) between Wesely (1989) and observed diurnal cycles appears for all of the sites examined. $\mathrm{Wu}$ et al. (2003a) indicates that, though the actual mechanisms by which some of the factors regulating stomatal opening are not well understood, methods that calculate stomatal conductance by considering photosynthesis and respiration processes have several advantages compared to the Jarvis method, one of them being the ability to better predict the diurnal cycle. However, it should be noted that, after 9 UTC, the mean observed and modeled deposition velocities compare well (see Fig. 4(c)). As the $\mathrm{O}_{3}$ surface concentration is usually higher at these day-hours, then this implies that the MOCAGE estimation of the overall $\mathrm{O}_{3}$ deposition flux is accurate.

At this site and for the period of interest, MOCAGE underestimates the peak amplitude of the $\mathrm{O}_{3}$ deposition velocity. As the stomatal resistance generally determines the deposition velocity during day light hours, we examined its various components and Fig. 5 shows model deposition velocities against $F_{1}, F_{2}, F_{3}, F_{4}$ values (see Eq. (2)). These $F_{1}$,
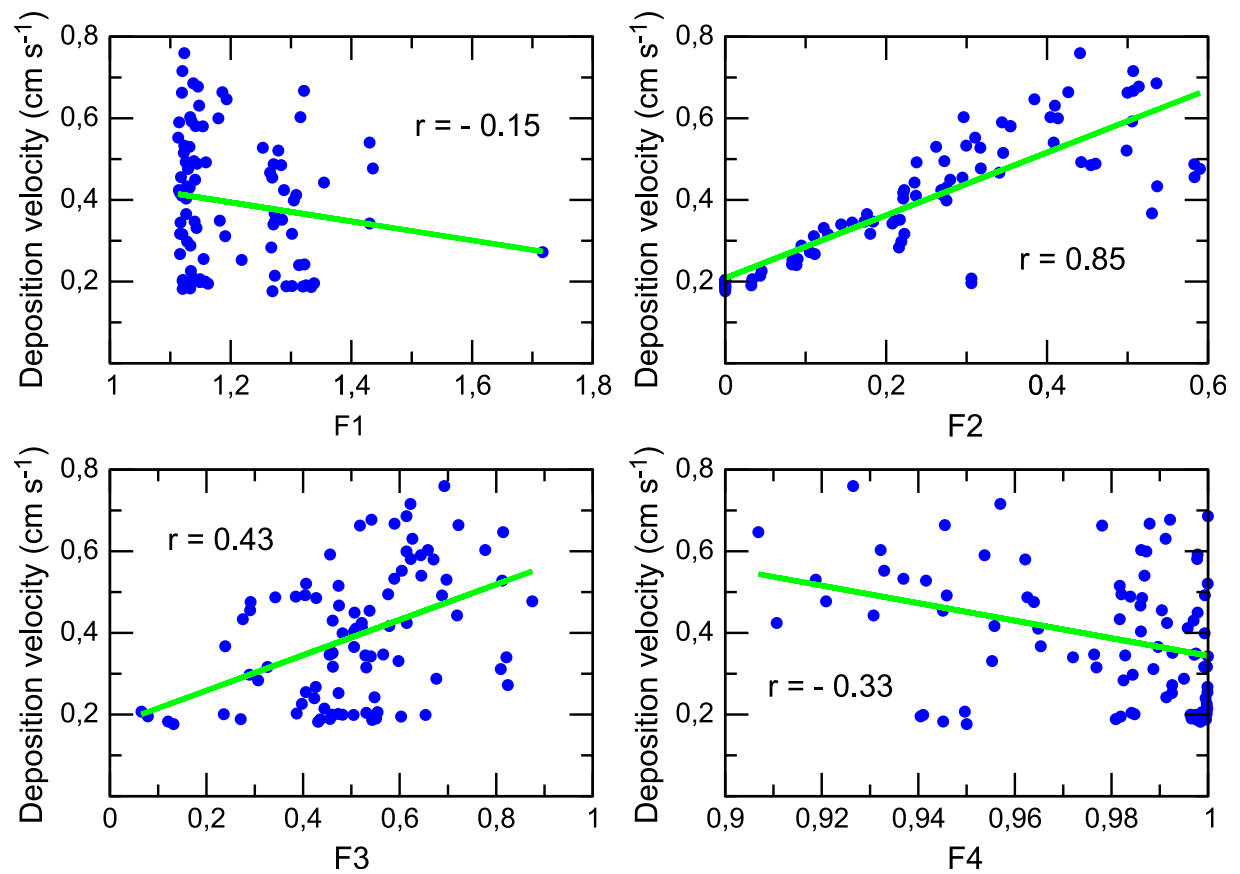

Fig. 5. Modeled deposition velocities of $\mathrm{O}_{3}$ for June 2001 at 09, 12 and 15 UTC over a Mediterranean forest (Montmeyan) against the various modeled terms of the stomatal resistance $F_{1}, F_{2}, F_{3}, F_{4}$ (see text and Eq. (2)). The correlation coefficient is reported on each graph. 
$F_{2}, F_{3}$, and $F_{4}$ values are MOCAGE outputs calculated with the meteorological and soil forcings simulated by ARPEGE. Though there is some correlation between the $F_{3}$ parameter (influence of water vapor deficit on the stomatal closure) and the deposition velocity, the striking feature is the strong correlation with the $F_{2}$ parameter (availability of water in the root zone) during day hours $(r=0.85)$. In addition, when the water content is under the wilting point, $F_{2}$ is set to a very small value that leads to a day-time resistance of $500 \mathrm{~s} \mathrm{~m}^{-1}$ and a velocity of $0.2 \mathrm{~cm} \mathrm{~s}^{-1}$, as on 13-15 June and on 21 June (Fig. 4(a) and (b)). Such low deposition velocities have not been measured. Model underpredictions of the $\mathrm{O}_{3}$ deposition velocity could be due to an inaccurate modeled soil water content, and/ or to an incorrect specification of the wilting point at this site.

\subsection{Ozone deposition velocities over Mediterranean shrub-land}

Mean and standard deviations of observed deposition velocities are somehow lower than those at the forest site (see Table 3), and these lower velocities could be related to the amount of vegetation. However, we can formulate similar comments about the average diurnal cycle as the ones we made in Section 5.2: here again, this cycle is asymmetrical (see Fig. 6(b)). Bouchou (2004) could separate the observations into two sets, comparable in terms of numbers of days, with and without dew. Clearly, deposition velocity increased earlier and the diurnal peak was higher (by more than $0.2 \mathrm{~cm} \mathrm{~s}^{-1}$ ) on the days with dew.

Observed and modeled deposition velocities at $0.08^{\circ}$ resolution appear to be poorly correlated: the diurnal cycles of both data sets are not well in phase; like at the forest site, this peak appears later in the model (9 UTC). Generally, the model peak value is maintained during several hours whereas spikes occur in the observed dry deposition because of the influence of small-scale processes such as the transient passage of clouds, that are hardly included in the model (forcings are available every $3 \mathrm{~h}$ ).

Modeled deposition velocities show fairly constant daily maxima throughout the entire period: as this is the case for the forest site on some days, here the model soil water content is below its wilting point on most days. This sets the stomatal resistance to the specified infinite value (see Eq. (2)), and the daily maximum deposition velocity of $\mathrm{O}_{3}$ to about 0.4 $\mathrm{cm} \mathrm{s}^{-1}$. On the contrary, night modeled velocities show some variability, with daily minima between 0.02 and $0.32 \mathrm{~cm} \mathrm{~s}^{-1}$.

\subsection{Ozone and nitrogen oxide deposition velocities over a bare soil}

\subsubsection{Ozone deposition}

Modeled and observed micro-meteorological conditions from 20 April to 31 May 2001 at La Crau are presented in Table 2. Overall, the model performed well, even if a slight overestimation was found for the maximum radiation $R_{\mathrm{g}}$, the minimum surface temperature $T_{\text {surf }}$, and the friction velocity $u *$. All these biases contributed to an overestimation of the $\mathrm{O}_{3}$ deposition velocity. The discrepancy in the soil humidities could be due to a wrong model estimate, or to uncertainties in the observations related to the estimation of the soil bulk density which was especially difficult to make due to the rocky texture of the soil. 
(a)

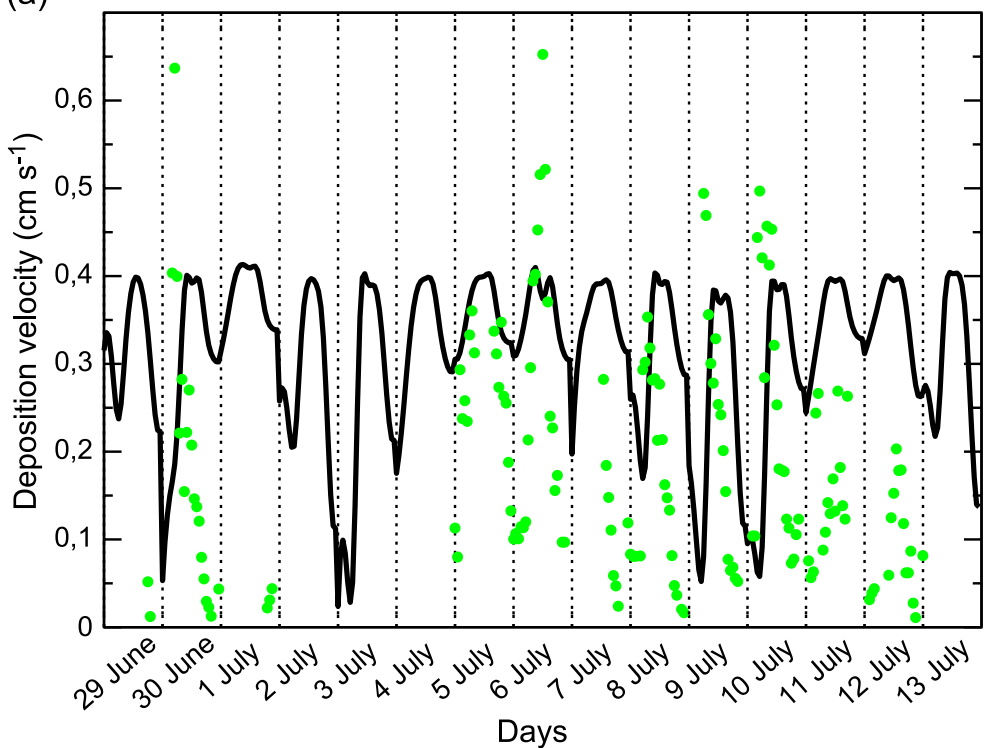

(b)

Days

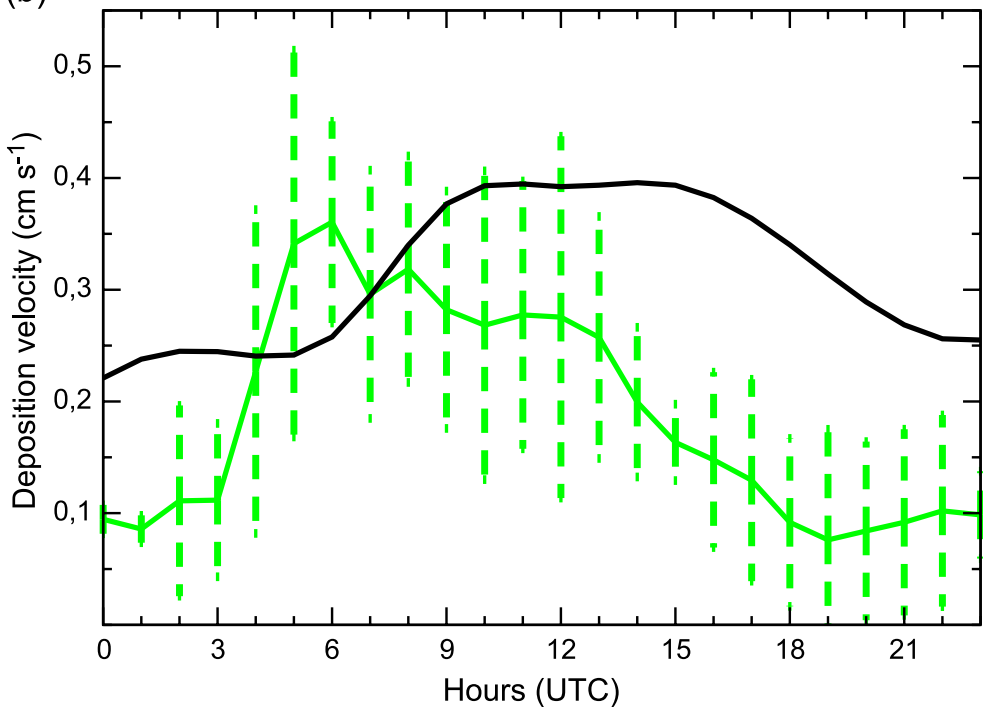

Fig. 6. $\mathrm{O}_{3}$ deposition velocities over a Mediterranean shrub-land (La Barben) from 29 June to 13 July 2001, observations are shown in grey, model outputs are shown in black. (a) Time series of hourly deposition velocity, observed and calculated by MOCAGE at $0.08^{\circ}$ resolution. (b) Average diurnal cycles over the period of observations (in dashed lines: standard deviations of observations).

The time series of the hourly observed deposition velocities (not presented here) revealed that the diurnal cycles presented peaks varying from 0.2 to $0.6 \mathrm{~cm} \mathrm{~s}^{-1}$. Here in the absence of vegetation, the mean velocity was a little higher than the one obtained at the shrub-land site $\left(0.21\right.$ vs. $\left.0.19 \mathrm{~cm} \mathrm{~s}^{-1}\right)$, and this is in contrast with other 
studies that outlined the importance of the stomatal pathway for $\mathrm{O}_{3}$ (e.g., Wesely and Hicks, 2000; Finkelstein et al., 2000). However, references indicate also that ozone removal by soil surfaces is highly variable, and can be as large as $1 \mathrm{~cm} \mathrm{~s}^{-1}$ (Wesely and Hicks, 2000). Again, as at the forest and shrub-land sites, deposition velocities started to increase between 3 and 4 UTC, but in this case they remained fairly steady from 5 to 12 UTC. However, Bouchou (2004) showed that in the presence of dew during the second part of the night there was a small peak (velocities higher by about $0.1 \mathrm{~cm} \mathrm{~s}^{-1}$ ) around 5 UTC. In the absence of vegetation, deposition velocities should be controlled by dynamical processes. Nevertheless, analyzing periods of strong winds, Bouchou (2004) concluded that higher turbulence was not always associated with higher deposition velocity, all other observed environmental conditions being quite similar.

MOCAGE $0.08^{\circ}$ resolution deposition velocities are higher than observations (bias of $0.30 \mathrm{~cm} \mathrm{~s}^{-1}$, see Table 3 and Fig. 7(a)). Differences in model and observed LAI are one of the causes for this model overestimation. Fig. 7(b) shows two model simulations over a three-day period, from 16 to 18 May, with two values of the LAI, 2.1 (model initial value), and 0.1 , to simulate an almost bare soil. The latter simulation results in reduced stomatal uptake, with day-time model deposition velocities in better agreement with observations. In addition, night-time model velocities approach closer to observations when one adjusts the initial roughness length $z_{0}(10 \mathrm{~cm}$ in the model $)$ to the observed value of $1.54 \mathrm{~cm}$; results of model sensitivity to the adjustment of the roughness length are presented in the next section.

At this stage of our analysis on the dry deposition velocity of $\mathrm{O}_{3}$, it appears that the dry deposition parameterization is not intrinsically erroneous, but that the non-linear effects of the sub-grid variability in the surface characteristics have to be taken into account over complex areas such as the ESCOMPTE domain, especially during the summer months characterized with higher deposition velocities. The use of sub-grid scale information, such as the one available for instance in the ECOCLIMAP database of land surface parameters at $1 \mathrm{~km}$ resolution (Masson et al., 2003), could lead to improved modeled deposition velocities. LAI, $R_{\text {smin }}$ and $z_{0}$ values used in MOCAGE and listed in the ECOCLIMAP database are presented in Table 4. In most cases, with no surprise, land cover parameters at $1 \mathrm{~km}$ resolution are closer to the local estimates than the $0.08^{\circ}$ resolution current model values; on the basis of the various sensitivities we have studied, we conclude that $1 \mathrm{~km}$ input parameters would lead to modeled deposition velocities closer to observations. In other words, the sensitivity of modeled deposition velocities on surface characteristic parameters is such that the spatial averaging, even at the relatively fine scale of approximately $10 \mathrm{~km}$, is strongly detrimental to model performance for such a region and such a period of the year (see Section 3). On the other hand, the meteorological forcings at $0.08^{\circ}$ resolution that we use in MOCAGE are satisfactory, even over such complex areas. Since surface modeling is by essence bi-dimensional, one computationally tractable approach for accurate dry deposition modeling could be the following: interpolate meteorological forcings at the scale of $1 \mathrm{~km}$; apply our parameterization at this very fine resolution using the ECOCLIMAP data; last, average the obtained deposition velocities at the larger scale of the 3D CTM grids (Noilhan and Lacarrère, 1995). 

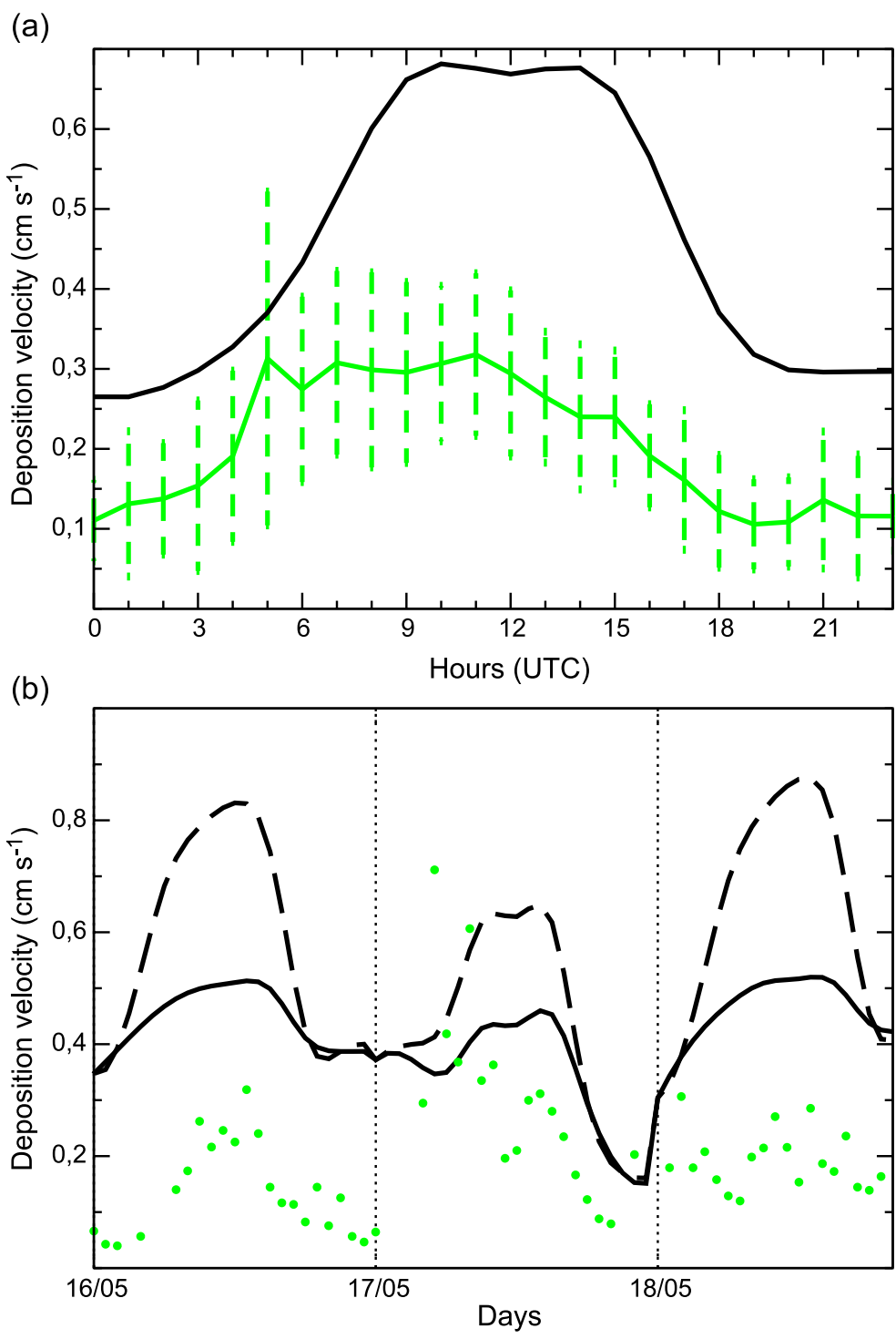

Fig. 7. (a) Average diurnal cycles of $\mathrm{O}_{3}$ deposition velocities over a bare soil (La Crau) between 20 April and 31 May 2001; model outputs (black), observations (grey) with standard deviations. (b) Sensitivity of the $\mathrm{O}_{3}$ model deposition velocity to the LAI for 3 days 16-18 May 2001: LAI=2.1 (dashed line); LAI=0.1 (solid line); observed deposition velocity (dots).

\subsubsection{Nitrogen oxide deposition}

Total nitrogen oxides, denoted $\mathrm{NO}_{y}$, comprise the individual species $\mathrm{NO}$ and $\mathrm{NO}_{2}$, together referred to as $\mathrm{NO}_{x}$, as well as a number of other species among which peroxyacetyl nitrate (PAN), $\mathrm{HNO}_{3}$, nitrous acid ( $\left.\mathrm{HONO}\right)$, and dinitrogen pentoxide $\left(\mathrm{N}_{2} \mathrm{O}_{5}\right)$. They are key species in the $\mathrm{O}_{3}$ photochemical cycle, being either active precursors, reservoirs or end 
Table 4

Modeled and observed land cover parameters in June 2001

\begin{tabular}{|c|c|c|c|c|}
\hline Site & Type & LAI & $R_{\mathrm{smin}}\left(\mathrm{s} \mathrm{m}^{-1}\right)$ & $\mathrm{z}_{0}(\mathrm{~m})$ \\
\hline \multirow[t]{3}{*}{ Meyragues } & Observed & $0.8-2.8$ & & $0.05-0.12$ \\
\hline & MOCAGE $0.08^{\circ}$ & 3.0 & 58 & 0.25 \\
\hline & ECOCLIMAP $1 \mathrm{~km}$ & 1.4 & 40 & 0.03 \\
\hline \multirow{3}{*}{ Montmeyan } & Observed & 2.3 & & 0.77 \\
\hline & MOCAGE $0.08^{\circ}$ & 3.8 & 97 & 1.72 \\
\hline & ECOCLIMAP $1 \mathrm{~km}$ & 3.9 & 150 & 1.30 \\
\hline \multirow[t]{3}{*}{ La Barben } & Observed & & & 0.03 \\
\hline & MOCAGE $0.08^{\circ}$ & 2.2 & 49 & 0.15 \\
\hline & ECOCLIMAP $1 \mathrm{~km}$ & 1.0 & 150 & 0.10 \\
\hline \multirow[t]{3}{*}{ La Crau } & Observed & $\sim 0$ & & 0.01 \\
\hline & MOCAGE $0.08^{\circ}$ & 2.1 & 49 & 0.10 \\
\hline & ECOCLIMAP $1 \mathrm{~km}$ & 1.3 & 40 & 0.03 \\
\hline
\end{tabular}

products, which behave very differently in the deposition process: for instance, the deposition velocity of $\mathrm{HNO}_{3}$ is an order of magnitude more important than the one of $\mathrm{NO}_{2}$, whereas the one of NO is close to zero. Fig. 8 compares the time profiles and average diurnal cycles of deposition velocities, observed with the $\mathrm{NO}-\mathrm{NO}_{2}-\mathrm{NO}_{x}$ analyser, and modeled for $\mathrm{NO}_{2}$ and $\mathrm{HNO}_{3}$. There is a possibility that the deposition measurements account in fact not only for $\mathrm{NO}_{x}$, but also for $\mathrm{NO}_{y}$ to some extent. Indeed, a rough comparison indicates that observed day-time values are one order of magnitude larger than modeled deposition velocities for $\mathrm{NO}_{2}$, and are more consistent with model outputs for $\mathrm{HNO}_{3}$. On the contrary, night-time observations are closer to $\mathrm{NO}_{2}$ model outputs than to $\mathrm{HNO}_{3}$ ones. We will investigate further these two aspects, using the model to help interpret the data. It should be noted that, in the surface module of MOCAGE, we do not consider currently the rapid in-air reactions between $\mathrm{NO}, \mathrm{NO}_{2}$, and $\mathrm{O}_{3}$ that may occur between the soil and the height at which the deposition velocity is computed. The processes of emission of NO from soils, rapid in-air reactions, and $\mathrm{NO}_{2}$ deposition still need to be evaluated, and such a task represents a significant challenge to modelers, especially if the processes are to be described adequately in regional and large-scale models (Wesely and Hicks, 2000). Ganzeveld et al. (2002a,b) present an atmosphere-biosphere trace gas exchange model with two layers of canopy that includes the processes cited by Wesely and Hicks (2000), and is aimed for use at the global scale. Comparisons of the $\mathrm{NO}_{x}$ fluxes calculated by the big-leaf approach, such as the one adopted in MOCAGE, and by the biosphere model confirms the applicability of the big-leaf approach for polluted regions. In the specific case of La Crau the soil was not a source of NO. NO was mainly advected from the neighboring Berre industrial area and Marseilles.

Daily observed maximum velocities are very high, in the order of $3 \mathrm{~cm} \mathrm{~s}^{-1}$, and occasionally up to $7 \mathrm{~cm} \mathrm{~s}^{-1}$. These values are higher than what has been usually reported for $\mathrm{NO}_{2}$ deposition velocities (see review in Fotiadi, 2003). It should be noted that the literature generally describes observations on vegetation and not on bare soils, as this is the case at La Crau. On the other hand, one could expect to have lower deposition velocities at La Crau than on vegetation as the La Crau roughness length is smaller than most vegetated surface roughness lengths. Two hypotheses have been formulated by Fotiadi (2003) to justify such high velocities at La Crau. The first hypothesis is that the characteristics of the 

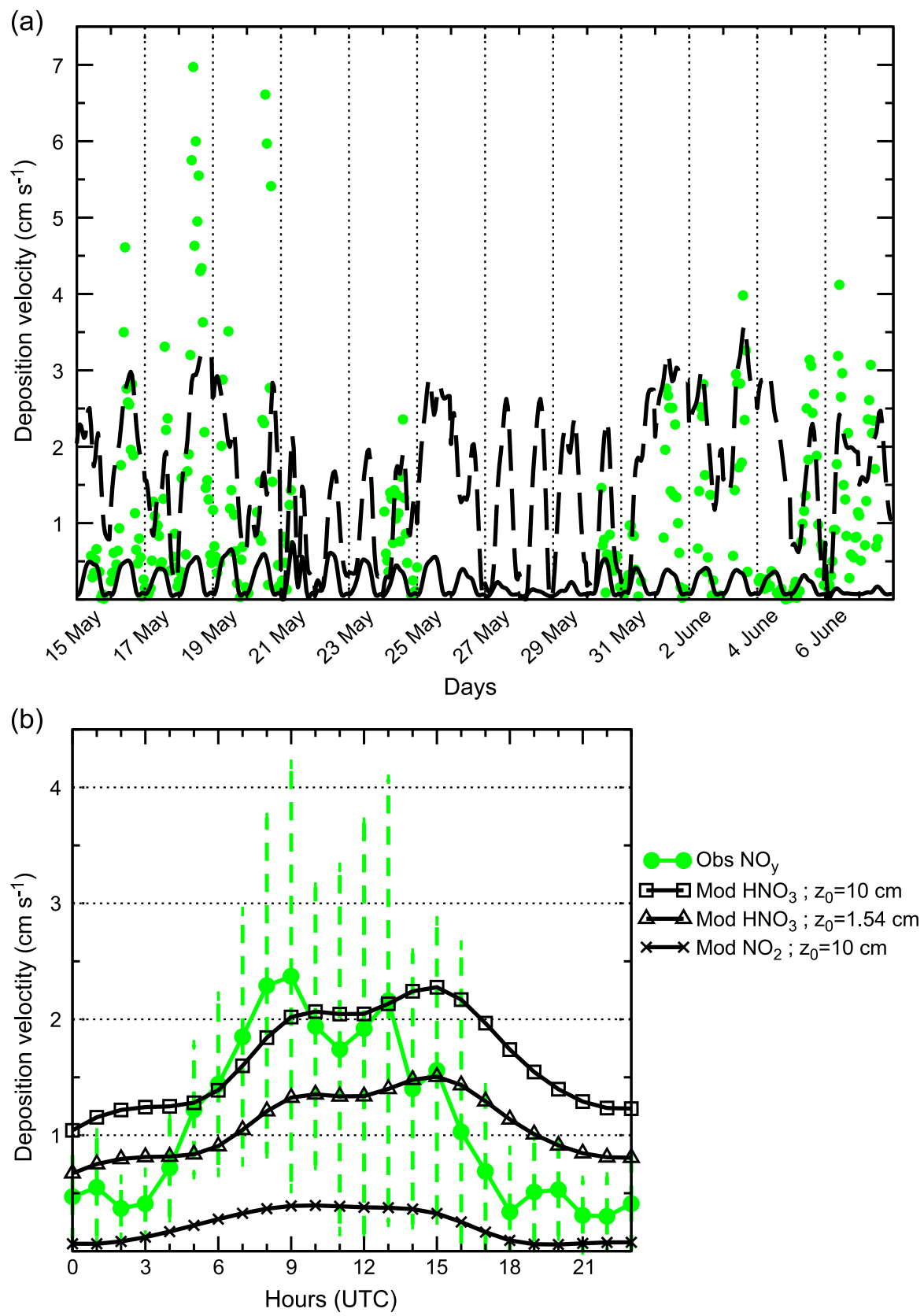

Fig. 8. Nitrogen oxide deposition velocities over a bare soil (La Crau) from 15 May to 7 June 2001. (a) Time series of hourly deposition velocity, observed $\left(\mathrm{NO}_{y}\right.$, dots) and calculated by MOCAGE at $0.08^{\circ}$ resolution $\left(\mathrm{HNO}_{3}\right.$ dashed line, and $\mathrm{NO}_{2}$ solid line). (b) Average diurnal cycles over the period of observations, observed $\mathrm{NO}_{y}$ (in dashed lines: standard deviations), MOCAGE $\mathrm{NO}_{2}$, and $\mathrm{HNO}_{3}$ at two different roughness lengths. 
analyser yield to measurements that are valid for $\mathrm{NO}_{y}$ rather than $\mathrm{NO}_{x}$, as the system appears to reduce into $\mathrm{NO}$ not only $\mathrm{NO}_{2}$ but also other nitrogen species such as $\mathrm{HNO}_{3}$. The second hypothesis formed is that this type of soil, which is very poor in organic matter, could fix atmospheric nitrogen at a very important rate using ecological processes which, though rather uncertain, have already been described in the literature. We will focus on the first hypothesis and test its probability in the light of our model results. In contrast to $\mathrm{NO}_{2}$, previously observed $\mathrm{HNO}_{3}$ deposition velocities better agree with our observations: Meyers et al. (1998) measured $\mathrm{HNO}_{3}$ deposition velocities over three different crops; mean day-time velocities ranged from 2.5 to $3.2 \mathrm{~cm} \mathrm{~s}^{-1}$. Brook et al. (1999) reports measurements made over various crops, forests and grass which generally range from 0 to $8 \mathrm{~cm} \mathrm{~s}^{-1}$, with occasional higher observations, up to $26 \mathrm{~cm} \mathrm{~s}^{-1}$.

$\mathrm{NO}_{x}$ mixing ratios have been measured simultaneously with fluxes at La Crau. Corresponding MOCAGE simulations for the period 16-18 June are presented in Fig. 9. A fair agreement is found: mixing ratios of $\mathrm{NO}_{x}$ vary from 0.5 to $29 \mathrm{ppb}$ in the model, with low values during the afternoon of the 16th and during the whole day of the 18th. On the 18th, established northerly winds (Fig. 9(c)) bring cleaner air, with lower $\mathrm{NO}_{x}$ concentrations, to the area. Unfortunately, the $\mathrm{NO}_{x} / \mathrm{NO}_{y}$ ratio has not been measured in situ at La Crau. From aircraft passing over the site in the Planetary Boundary Layer, it is estimated that this ratio ranged from $1 / 3$ to $4 / 5$, with air masses being either polluted air from the South, coming directly from the Berre Pond industrial area, or relatively clean air, coming from the North during Mistral wind conditions (Fotiadi, 2003). In the former case (recently polluted air mass), $\mathrm{NO}_{x}$ have not yet oxidized into so-called $\mathrm{NO}_{z}\left(\mathrm{NO}_{z}=\mathrm{NO}_{y}-\right.$ $\mathrm{NO}_{x}$ ), thus the $\mathrm{NO}_{x} / \mathrm{NO}_{y}$ ratio is close to 1; in the latter case, the air mass being older and arguably originally less polluted (since air masses go along the industrial Rhone Valley), a large part of the initial $\mathrm{NO}_{x}$ is oxidized, decreasing the $\mathrm{NO}_{x} / \mathrm{NO}_{y}$ ratio. We also present in Fig. 9 (b) the time series of the $\mathrm{NO}_{x} / \mathrm{NO}_{y}$ ratio modeled by MOCAGE at the model lowest level (approximately $20 \mathrm{~m}$ above ground). During the periods of low $\mathrm{NO}_{x}$ concentrations, the $\mathrm{NO}_{x} / \mathrm{NO}_{y}$ ratio calculated by MOCAGE is below 0.7 , and down to 0.27 on the 18 th; simultaneously, the REA system measured high deposition velocities, from 3 to $7 \mathrm{~cm} \mathrm{~s}^{-1}$ (see Fig. 9(d)). On the 18th, the combined effects of low $\mathrm{NO}_{x} / \mathrm{NO}_{y}$ ratios and of a large turbulence lead to the highest deposition velocities measured during the period of observations (see Figs. 8 and 9). By sharp contrast, with high concentrations of $\mathrm{NO}_{x}$, and high $\mathrm{NO}_{x} / \mathrm{NO}_{y}$ ratios $(>0.8)$, as on May $17 \mathrm{th}$, caused by direct import of $\mathrm{NO}_{x}$ from the FosBerre area with Southerly winds, lower deposition velocities have been measured. It appears that the model corroborates the first hypothesis formulated concerning the high deposition velocities measured: to a noticeable extent, the high deposition velocities could be related to deposition of $\mathrm{HNO}_{3}$. However, additional measurements need to confirm this hypothesis, and at the same time further validate the REA system fluxes that are rather new.

We compared 280 hourly observations to modeled $\mathrm{NO}_{2}$ and $\mathrm{HNO}_{3}$ deposition velocities in the matching MOCAGE $0.08^{\circ}$ resolution cell. $\mathrm{HNO}_{3}$ velocities are the highest we model, as our surface $\mathrm{HNO}_{3}$ resistance is set to a small value of $10 \mathrm{~s} \mathrm{~m}^{-1}$ (see Michou and Peuch (2002)). $\mathrm{HNO}_{3}$ is thus deposited as rapidly as the turbulent transfer allows. During day light hours, mean observations and model values match reasonably well, but the variability of observations is quite large (standard deviation of $1.46 \mathrm{~cm} \mathrm{~s}^{-1}$ ), larger than that of MOCAGE outputs $\left(0.71 \mathrm{~cm} \mathrm{~s}^{-1}\right)$. This is in contrast with night-time values 
(a)
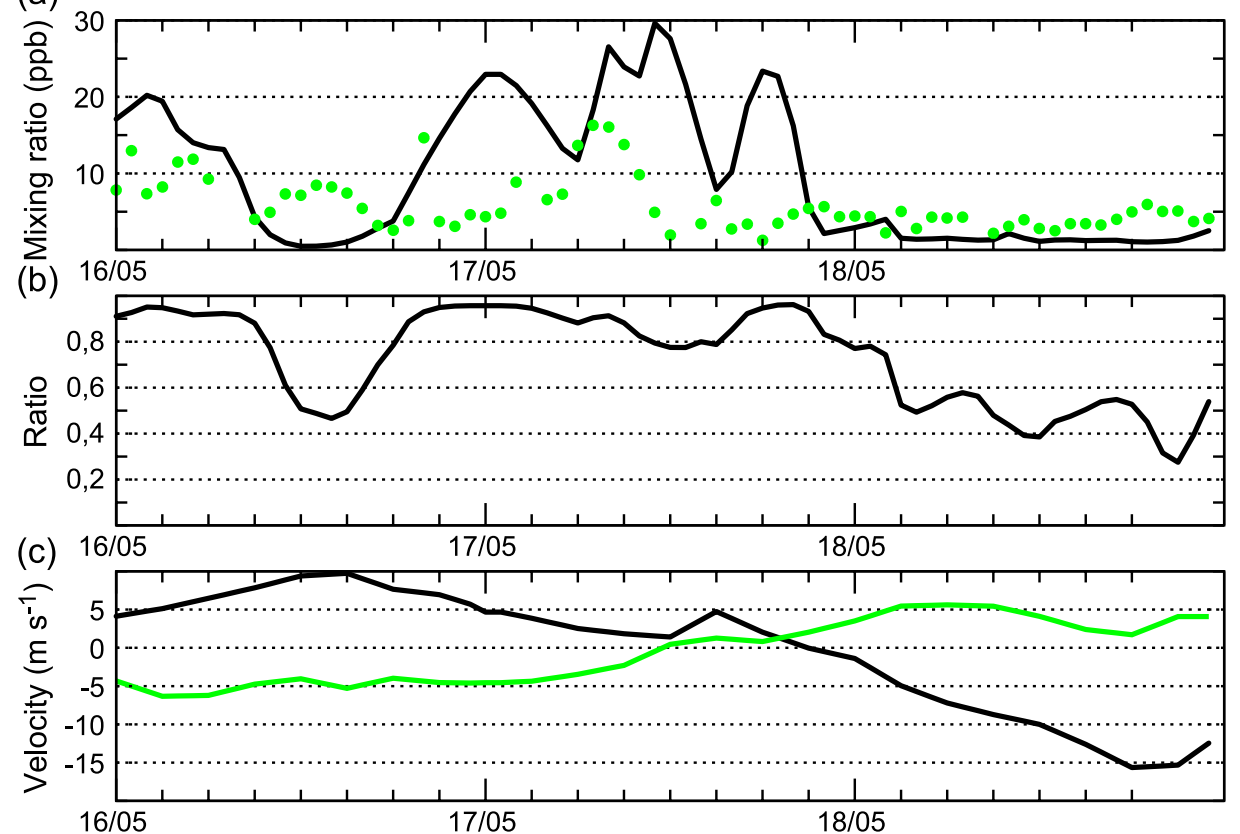

(d)

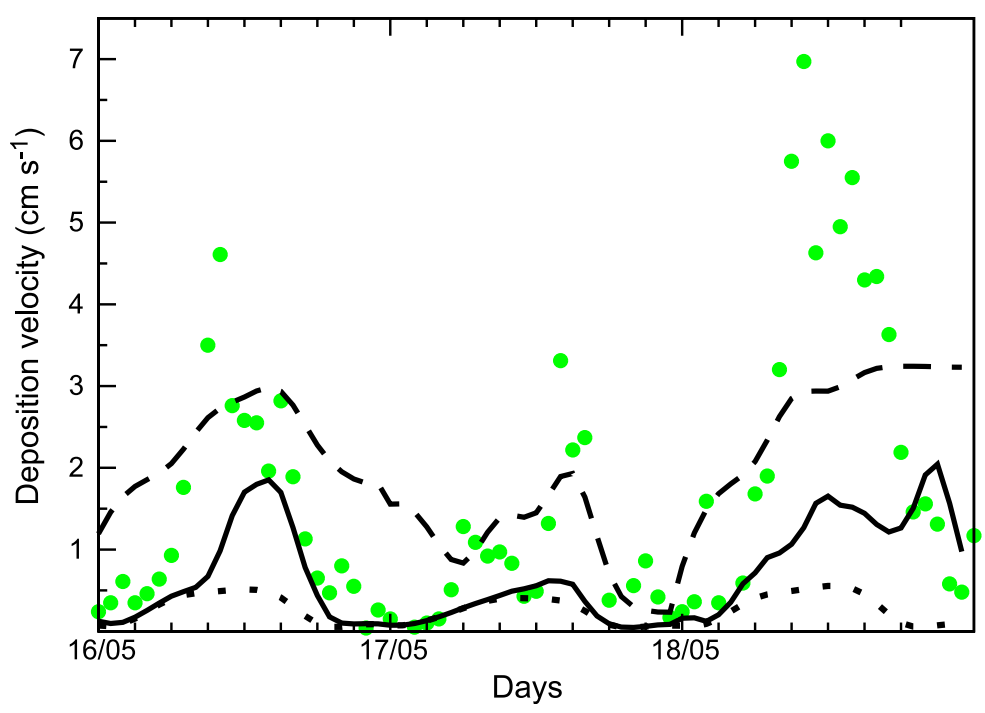

Fig. 9. Time series of hourly values from 16 to 18 May 2001. (a) $\mathrm{NO}_{x}$ concentrations, observed (dots), and modeled (line). (b) Modeled $\mathrm{NO}_{x} / \mathrm{NO}_{y}$ ratio. (c) Model wind velocity, meridional wind (black), zonal wind (greypositive meridional wind=Southerly wind, positive zonal wind=Westerly wind). (d) Observed $\mathrm{NO}_{y}$ (spots), modeled $\mathrm{HNO}_{3}$ (dashed) and $\mathrm{NO}_{2}$ (dots) deposition velocities for 3 days 16-18 May 2001. The solid line shows the "composite" of the two species $\mathrm{HNO}_{3}$ and $\mathrm{NO}_{2}$ as described in the text. 
when the variability of observations is small $\left(0.46 \mathrm{~cm} \mathrm{~s}^{-1}\right)$, and smaller than that of modeled velocities $\left(0.95 \mathrm{~cm} \mathrm{~s}^{-1}\right)$. During day light hours, MOCAGE $\mathrm{HNO}_{3}$ velocities are smaller than observations, with a maximum of $3.6 \mathrm{~cm} \mathrm{~s}^{-1}$ obtained with $R_{\mathrm{a}}=12 \mathrm{~s} \mathrm{~m}^{-1}$ and $R_{\mathrm{b}}=6 \mathrm{~s} \mathrm{~m}^{-1}$. If we set the surface resistance to 0 instead of 10 , as suggested for instance in Wesely and Hicks (2000), this maximum velocity increases up to $5.5 \mathrm{~cm} \mathrm{~s}^{-1}$. During night-time hours, model velocities are too high and several possible explanations can be put forward. Part of the difference is due to a $z_{0}$ being too large $(10 \mathrm{~cm}$ in the model against the observed value of $1.54 \mathrm{~cm}$ ): a simulation with the observed $z_{0}$, performed as presented in Section 5.1, resulted in the diurnal cycle presented in Fig. 8(b): hourly differences between model outputs with the two $z_{0}$ range from 0.37 to $0.77 \mathrm{~cm} \mathrm{~s}^{-1}$. Another part of this difference has been reported in the literature: Wesely and Hicks (2000) indicates that for substances such as $\mathrm{HNO}_{3}$, that have very small values of surface resistance and whose deposition velocity is mainly controlled by turbulence, the uncertainties in deposition velocity induced by the aerodynamic resistance $R_{\mathrm{a}}$ are large. Very low deposition appear though correctly modeled during a few nights, as on 18 May, 21 May, 31 May or 6 June.

We put in place a simple model that used observed meteorological information to compute $\mathrm{HNO}_{3}$ deposition velocity. $V_{\mathrm{dHNO}_{3}}$ was expressed as $V_{\mathrm{dHNO}_{3}}=1 / R_{\mathrm{a}}$, and $R_{\mathrm{a}}=u / u_{*}^{2}$, formulation that we use in MOCAGE, with u wind velocity measured at $8 \mathrm{~m}$, and $u *$ friction velocity calculated from observations. We obtained a maximum $V_{\mathrm{dHNO}_{3}}$ of $5.6 \mathrm{~cm} \mathrm{~s}^{-1}$. It should be noted that the expression $R_{\mathrm{a}}=u / u_{*}^{2}$ is correct in stable or neutral conditions as a first-order approximation. In unstable cases, however, this simplified expression of $R_{\mathrm{a}}$ could lead to errors in the estimation of the deposition velocity of species such as $\mathrm{HNO}_{3}$, as $R_{\mathrm{a}}$ determines the dry deposition velocity in this case. At the site of La Crau, deposition velocities higher than $5.6 \mathrm{~cm} \mathrm{~s}^{-1}$ have been observed several times, and both the approximation in the formulation of $R_{\mathrm{a}}$ and the measurements uncertainties could explain our only relative success in matching simulations and observations of the deposition velocity.

Finally, we have used the modeled concentrations of $\mathrm{NO}_{2}$ and $\mathrm{HNO}_{3}$ to derive a composite $\mathrm{NO}_{y}$ deposition velocity, which could be more directly comparable to observations. We simply estimated the total nitrogen oxide deposition velocity by computing the nitrogen oxide flux as the sum of the modeled $\mathrm{NO}_{2}$ and $\mathrm{HNO}_{3}$ fluxes, and by dividing this flux by the sum of the concentrations of these two species. Even though this averaging cannot of course result in composite $\mathrm{NO}_{y}$ deposition velocities higher than the ones for $\mathrm{HNO}_{3}$ - meaning that the combined effect of a lower roughness length and a lower surface resistance for $\mathrm{HNO}_{3}$ are indeed important to be closer to the in situ conditions - we obtain a satisfactory comparison to the observations during the night, as demonstrated in Fig. 9((d), solid line).

\section{Conclusions}

Measurements of the dry deposition velocity of $\mathrm{O}_{3}$ and nitrogen oxides have been made during ESCOMPTE over a range of ecosystems, chosen for their representativity of the main land-use types. In three of the four sites studied, very early morning peaks (around 6 UTC) of 
the deposition velocity of $\mathrm{O}_{3}$ were observed, with velocity starting to increase at 3 UTC, even before any light had reached the vegetation; early opening of the stomata and increased surface wetness because of dew could explain this feature. Deposition velocities computed within the surface module of the 3D CTM MOCAGE were evaluated. The simulated yearly cycle captured the main seasonal features of deposition in the Mediterranean region, but the summer months were the most challenging to model. Overall, the raw comparison of the model deposition velocities with the observations of the cases and sites documented in ESCOMPTE were rather unsatisfactory. Using sensitivity studies, we outlined that the model performance strongly depended on the specification of land use types and associated characteristics, such as the minimum stomatal resistance, the roughness length, or the leaf area index. Overall, by fixing the land cover parameters to their local evaluation, the model was able to reproduce rather accurately observations, suggesting that the dry deposition parameterization was not intrinsically erroneous, but that the effect of the sub-grid variability in the surface characteristics had to be taken into account. The use of a high-resolution database is advocated, as well as the need for a good specification of soil moisture. Concerning this last point, routine remotely sensed measurements (for instance within the European project SMOS) of the soil water content are a key to progress in the numerical simulation of the surface energy budget, evapotranspiration and surface deposition. Finally, it appeared that MOCAGE outputs such as compound concentrations and deposition velocities could help interpreting qualitatively and quantitatively the rather complex dry deposition measurements of nitrogen oxides.

\section{Acknowledgements}

Our warm thanks go to J.-L. Champeaux, A. Dufour and H. Clark (Météo-France) for the ECOCLIMAP land cover map, MOCAGE outputs and helpful comments, and to L. Ganzeveld (MPI for Chemistry) as well as to the late M.L. Wesely for very useful discussions. We also would like to thank two anonymous reviewers for their very constructive suggestions.

\section{References}

Bouchou, P., 2004. Quantification et élément de paramétrisation du dépôt sec de l'ozone à l'interface sol/ végétation atmosphère au-dessus de trois écosystèmes méditerranéens (programme ESCOMPTE), $\mathrm{PhD}$ thesis, Université Paul Sabatier, Toulouse.

Bougeault, P., Noilhan, J., Lacarrère, P., Mascart, P., 1991. An experiment with an advanced surface parameterisation in a mesobeta-scale model: Part I. Implementation. Monthly Weather Review 119, 2358-2373.

Brook, J.R., Zhang, L., Li, Y., Johnson, D., 1999. Description and evaluation of a model of deposition velocities for routine estimates of dry deposition over North America. Atmos. Environ. 33, 5053-5070.

Calvet, J.-C., Noilhan, J., Roujean, J.-L., Bessemoulin, P., Cabelguenne, M., Olioso, A., Wigneron, J.-P., 1998. An interactive vegetation SVAT model tested against data from six contrasting sites. Agric. For. Meteorol. 92, $73-95$. 
Cathala, M.-L., Pailleux, J., Peuch, V.-H., 2003. Improving global chemical simulations of the upper tropospherelower stratosphere with sequential assimilation of MOZAIC data. Tellus 55B, 1-10.

Champeaux, J.-L., Arcos, D., Bazile, E., Giard, D., Goutorbe, J.-P., Habets, F., Noilhan, J., Roujean, J.-L., 1999. AVHRR-derived vegetation mapping over western Europe for use in numerical weather prediction models. Int. J. Remote Sens. 21, 1183-1199.

Cooter, E.J., Schwede, D.B., 2000. Sensitivity of the national oceanic and atmospheric administration multilayer model to instrument error and parameterisation uncertainty. J. Geophys. Res. 105, 6695-6707.

Courtier, Ph., Freydier, C., Geleyn, J.F., Rabier, F., Rochas, M., 1991. The ARPEGE projet at METEO-FRANCE. ECMWF Seminar Proceedings, Reading, 9-13 Sept 1991, vol. II, pp. 193-231.

Cros, B., Durand, P., Cachier, H., Drobinski, Ph., Fréjafon, E., Kottmeier, C., Perros, P.E., Peuch, V.-H., Ponche, J.L., Robin, D., Saï, F., Toupance, G., Wortham, H., 2004. The ESCOMPTE program: an overview. Atmos. Res. 69, 241-279.

Dufour, A., Amodei, M., Ancellet, G., Peuch, V.H., 2004. Observed and Modelled 'Chemical Weather' during ESCOMPTE, Atmos. Res. 74, 161-189 (this issue).

Finkelstein, P.L., Ellestad, T.G., Clarke, J.F., Meyers, T.P., Schwede, D.B., Hebert, E.O., Neal, J.A., 2000. Ozone and sulfur dioxide dry deposition to forests: observations and model evaluation. J. Geophys. Res. 105 (D122), $15365-15377$.

Fotiadi, A.K., 2003. Echanges biosphère-atmosphère des oxydes d'azote et de l'isoprène en région Méditerrannéenne (programme ESCOMPTE), Ph.D thesis, Université Paul Sabatier, Toulouse.

Fotiadi, A.K., Lohou, F., Druilhet, A., Serça, D., Brunet, Y., Delmas, R., 2004a. Methodological development on the conditional sampling method: Part 1. Sensitivity to statistical and technical characteristics. BoundaryLayer Meteorol. (in press).

Fotiadi, A.K., Lohou, F., Druilhet, A., Serça, D., Said, F., Laville, P., Brut, A., 2004b. Methodological development on the conditional sampling method: Part 2. quality control criteria of relaxed eddy accumulation fluxes measurements. Boundary-Layer Meteorol. (in press).

Ganzeveld, L., Lelieveld, J., 1995. Dry deposition parameterization in a chemistry general circulation model and its influence on the distribution of reactive trace gases. J. Geophys. Res. 100 (D10), 20999-21012.

Ganzeveld, L., Lelieveld, J., Roelofs, G.-J., 1998. A dry deposition parameterization for sulfur oxides in a chemistry and general circulation model. J. Geophys. Res. 103 (D5), 5679-5694.

Ganzeveld, L., Lelieveld, J., Dentener, F.J., Krol, M.C., Roelofs, G.-J., 2002a. Atmosphere-biosphere trace gas exchanges simulated with a single-column model. J. Geophys. Res. 107 (D16).

Ganzeveld, L., Lelieveld, J., Dentener, F.J., Krol, M.C., Bouwman, A.J., Roelofs, G.-J., 2002b. Global soilbiogenic $\mathrm{NO}_{x}$ emissions and the role of canopy processes. J. Geophys. Res. 107 (D16).

Giard, D., Bazile, E., 2000. Implementation of a new assimilation scheme for soil and surface variables in a global NWP model. Mon. Weather Rev. 128, 997-1015.

Güsten, H., 1992. A novel ozone sensor for various environmental applications. In: Hudson, R.D. (Ed.), Ozone in the troposphere and stratosphere, Part 1, NASA Conference Publication, vol. 3266. Goddard Space Flight Center, Greenbelt, MD, USA, pp. 127-129.

Kirkman, G.A., Gut, A., Ammann, C., Gatti, L.V., Cordova, A.M., Moura, M.A.L., Andreae, M.O., Meixner, F.X., 2002. Surface exchange of nitric oxide, nitrogen dioxide, and ozone at a cattle pasture in Rondonia, Brazil. J. Geophys. Res. 107 (D20), 8083.

Lamaud, E., Carrara, A., Brunet, Y., Lopez, A., Druilhet, A., 2002. Ozone fluxes above and within a pine forest canopy in dry and wet conditions. Atmos. Environ. 36, 77-88.

Lelieveld, J., Berresheim, H., Borrmann, S., Crutzen, P.J., Dentener, F.J., Fischer, H., Feichter, J., Flatau, P.J., Heland, J., Holzinger, R., Kormann, R., Lawrence, M.B., Levin, Z., Markowicz, K., Mihalopoulos, N., Minikin, A., Ramanthan, V., de Reus, M., Roelofs, G.J., Scheeren, H.A., Sciare, J., Schlager, H., Schulz, M., Siegmund, P., Steil, B., Stephanou, E.G., Stier, P., Traub, M., Warneke, C., Williams, J., Ziereis, H., 2002. Global air pollution crossroads over the Mediterranean. Science 298, 794-799.

Masson, V., Champeaux, J.-L., Chauvin, F., Meriguet, C., Lacaze, R., 2003. A global database of land surface parameters at 1-km resolution in meteorological and climate models. J. Climate 16 (9), 1261-1282.

Meyers, T.P., Finkelstein, P., Clarke, J., Ellestad, T.G., Sims, P.F., 1998. A multilayer model for inferring dry deposition using standard meteorological measurements. J. Geophys. Res. 103 (D17), 22645-22661.

Michou, M., Peuch, V.-H., 2002. Surface exchanges in the MOCAGE multiscale chemistry and transport model. J. Water Sci. 15, 173-203. (no special). 
Nho-Kim, E.-Y., Michou, M., Peuch, V.-H., 2004. Parameterization of size dependent particle dry deposition velocities for global modeling. Atmos. Environ. 38/13, 1933-1942.

Niyogi, D., Raman, S., 1997. Comparison of four different stomatal resistance schemes using FIFE observations. J. Appl. Meteorol. 36, 903-917.

Niyogi, D., Alapaty, K., Raman, S., 2003. Photosynthesis based dry deposition modeling approach. Water Air Soil Pollut. 44, $171-193$.

Noilhan, J., Lacarrère, P., 1995. GCM grid-scale evaporation from mesoscale modeling. J. Climate 8, $206-223$.

Noilhan, J., Mahfouf, J.-F., 1996. The ISBA land surface parameterisation. Glob. Planet. Change 13, $145-159$.

Peuch, V.-H., Amodei, M., Barthet, T., Cathala, M.-L., Josse, B., Michou, M., Simon, P., 1999. MOCAGE: Modèle de Chimie Atmosphrique Grande Echelle. Actes des Ateliers de Modélisation de l'Atmosphère, Météo-France, pp. 33-36.

Pio, C.A., Feliciano, M.S., Vermeulen, A.T., Sousa, E.C., 2000. Seasonal variability of ozone dry deposition under southern European climate conditions, in Portugal. Atmos. Environ. 34, 195-205.

Pryor, S.C., Barthelmie, R.J., Jensen, B., Jensen, N.O., Sorensen, L.L., 2002. $\mathrm{HNO}_{3}$ fluxes to a deciduous forest derived using gradient and REA methods. Atmos. Environ. 36, 5993-5999.

Wesely, M.L., 1989. Parameterization of surface resistances to gaseous dry deposition in regional-scale numerical models. Atmos. Environ. 23 (6), 1293-1304.

Wesely, M.L., Hicks, B.B., 2000. A review of the current status of knowledge on dry deposition. Atmos. Environ. 34, 2261-2282.

Wu, Y., Brashers, B., Finkelstein, P.L., Pleim, J.E., 2003a. A multilayer biochemical dry deposition model: 1. Model formulation. J. Geophys. Res. 108 (D1), 4013.

Wu, Y., Brashers, B., Finkelstein, P.L., Pleim, J.E., 2003b. A multilayer biochemical dry deposition model: 2. Model evaluation. J. Geophys. Res. 108 (D1), 4014.

Zhang, L., Brook, J.R., Vet, R., 2002. On ozone dry deposition-with emphasis on non-stomatal uptake and wet canopies. Atmos. Environ. 36, 4787-4799. 